US Army Corps

of Engineers ${ }_{\circledast}$

Engineer Research and

Development Center

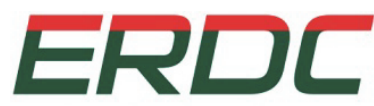

INNOVATIVE SOLUTIONS

for a safer, better world

\title{
Snow Water Equivalent Modeling Capabilities of the GSSHA Watershed Model
}

Project Report

Michael L. Follum and Charles W. Downer

June 2013

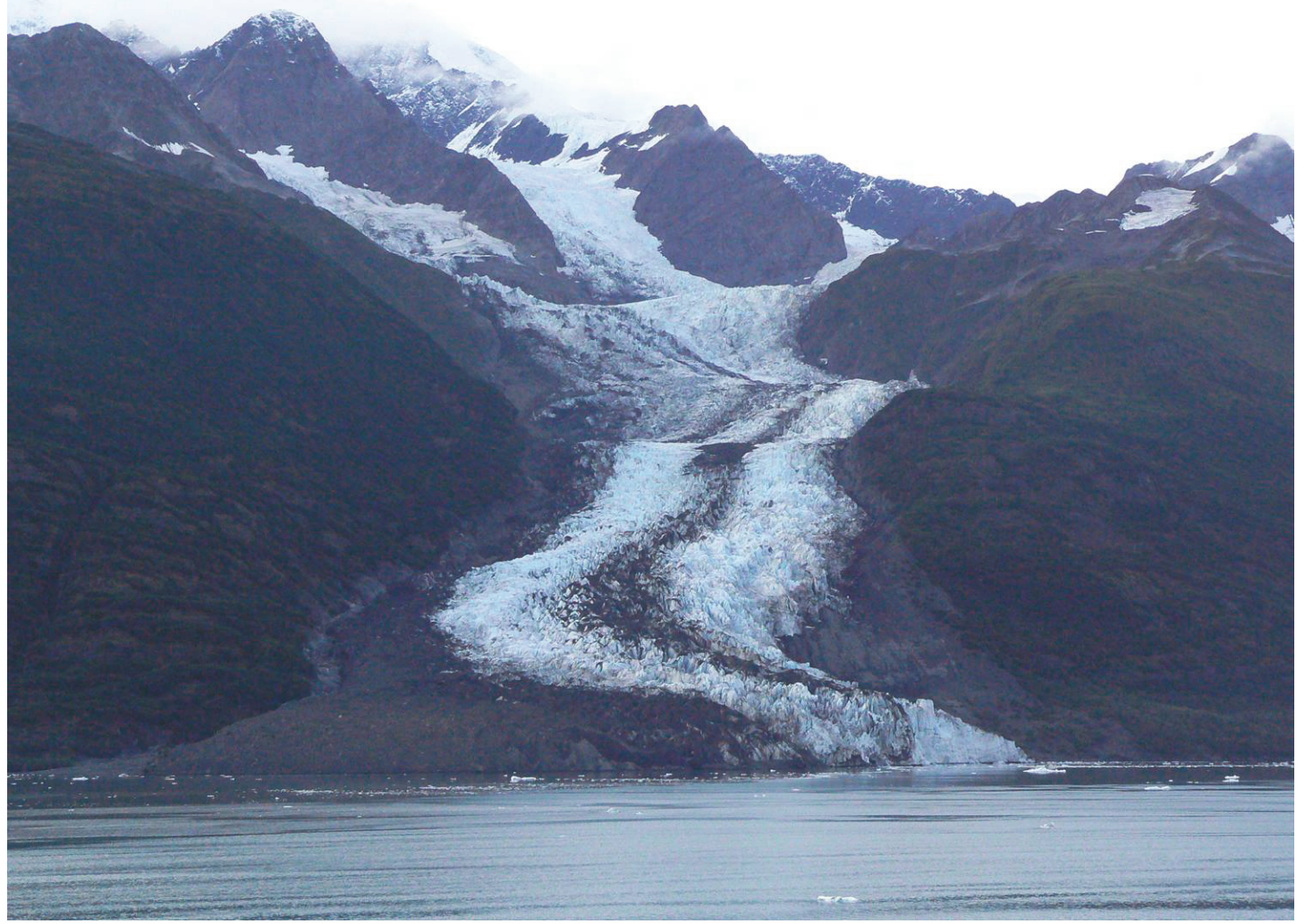

Picture courtesy of Earl V. Edris 
The US Army Engineer Research and Development Center (ERDC) solves the nation's toughest engineering and environmental challenges. ERDC develops innovative solutions in civil and military engineering, geospatial sciences, water resources, and environmental sciences for the Army, the Department of Defense, civilian agencies, and our nation's public good. Find out more at www.erdc.usace.army.mil.

To search for other technical reports published by ERDC, visit the ERDC online library at http://acwc.sdp.sirsi.net/client/default. 


\section{Snow Water Equivalent Modeling Capabilities of the GSSHA Watershed Model}

Project Report

Michael L. Follum and Charles W. Downer

Coastal and Hydraulics Laboratory

US Army Engineer Research and Development Center

3909 Halls Ferry Road

Vicksburg, MS 39180-6199

Final report

Approved for public release; distribution is unlimited.

Prepared for US Army Corps of Engineers

$441 \mathrm{G}$ Street NW

Washington, DC 20314-1000 


\section{Abstract}

This report demonstrates the snow water equivalent (SWE) modeling capabilities present within the Gridded Surface Sub-surface Hydrologic Analysis (GSSHA) model (Downer and Ogden 2004, 2006) by comparing simulated and observed snow accumulation data. GSSHA is widely used in both military and civil works projects to simulate runoff, streamflow, and sediment and constituent transport. GSSHA originally employed an energy balance method for calculating snow accumulation and melt, but now has an optional temperature-index method and hybrid energy balance method (explained within this report) as well. The full snowpack modeling capabilities of the Snowmelt Numerical-Analytical Package (SNAP) model (Albert and Krajeski 1998) have also been included to simulate snow pack depth and density regardless of which of the three snow accumulation models are employed. With proficient SWE modeling capabilities, the GSSHA model can be utilized to solve complex watershed-related issues in regions where snow accumulation and melt are often the most critical source of water.

DISCLAIMER: The contents of this report are not to be used for advertising, publication, or promotional purposes. Citation of trade names does not constitute an official endorsement or approval of the use of such commercial products. All product names and trademarks cited are the property of their respective owners. The findings of this report are not to be construed as an official Department of the Army position unless so designated by other authorized documents. 


\section{Contents}

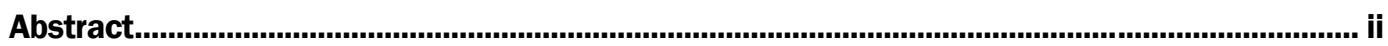

Figures and Tables....................................................................................................................

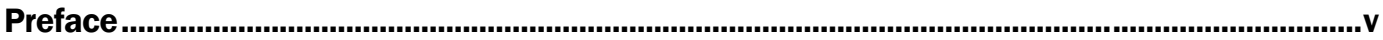

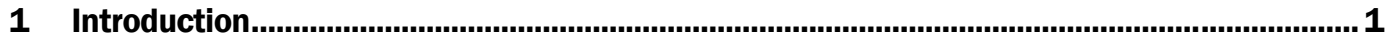

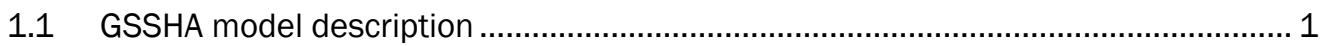

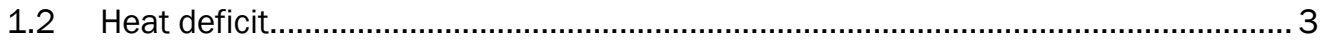

1.2.1 Energy flux heat deficit due to temperature gradients ............................................ 3

1.2.2 Mass change heat deficit due to precipitation ........................................................... 4

2 Description of the Snow Accumulation and Melt Methods: ............................................... 6

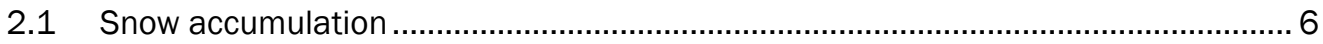

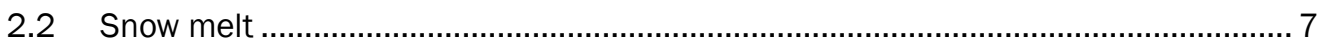

2.2.1 Energy balance method ................................................................................. 7

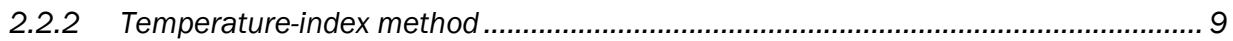

2.2.3 Hybrid energy balance method ........................................................................... 11

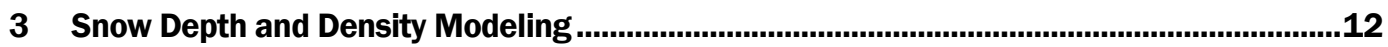

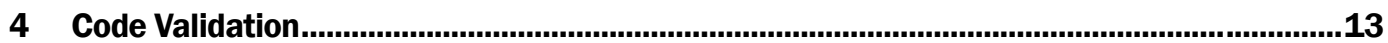

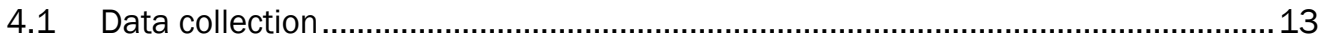

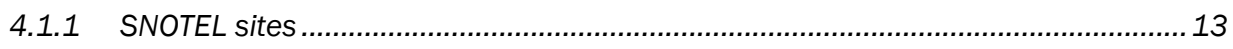

4.1.2 Lake Tahoe airport data ..............................................................................14

4.1.3 Senator Beck Basin study area data ................................................................... 15

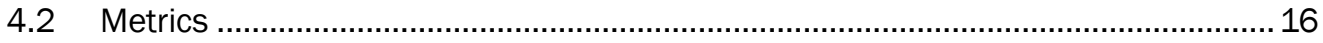

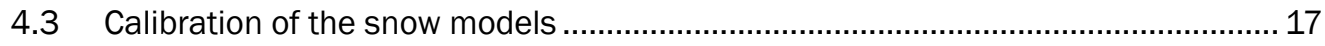

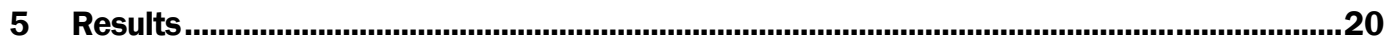

5.1 Dry Lake, Colorado site results ......................................................................... 22

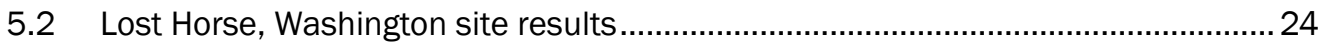

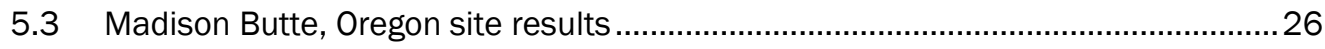

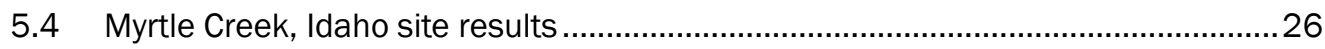

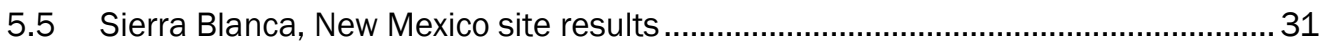

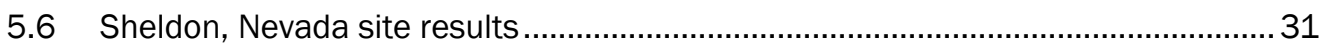

5.7 Hagan's Meadow, California site results......................................................... 31

5.8 Swamp Angel, Colorado site results .............................................................. 31

5.9 Senator Beck Basin, Colorado site results....................................................... 32

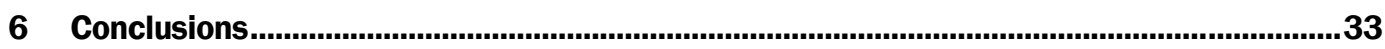

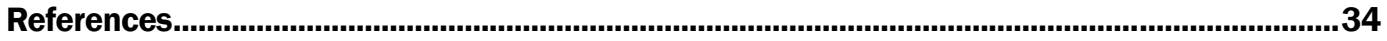

\section{Report Documentation Page}




\section{Figures and Tables}

\section{Figures}

Figure 1. Structured grid format of the GSSHA Trout Creek river basin, California model .................. 2

Figure 2. Collected data locations. ................................................................................................ 14

Figure 3. Hagan's Meadow and Lake Tahoe airport locations. ........................................................ 15

Figure 4. Senator Beck Basin, Colorado. ............................................................................................ 16

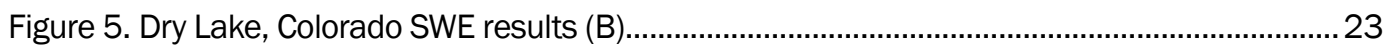

Figure 6. Lost Horse, Washington SWE results (B) . ........................................................................ 24

Figure 7. Madison Butte, Oregon SWE results........................................................................... 25

Figure 8. Myrtle Creek, Idaho SWE results. .................................................................................... 25

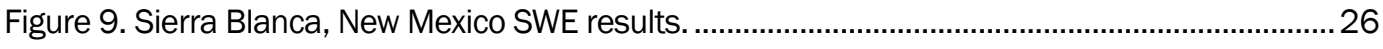

Figure 10. Sheldon, Nevada SWE results (A)..................................................................... 27

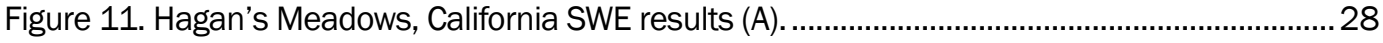

Figure 12. Swamp Angel study plot, Colorado SWE sesults............................................................ 29

Figure 13. Swamp Angel study plot, Colorado snow depth results.................................................2

Figure 14. Senator Beck Basin study plot, Colorado SWE results...................................................30

Figure 15. Senator Beck Basin study plot, Colorado snow depth results........................................30

\section{Tables}

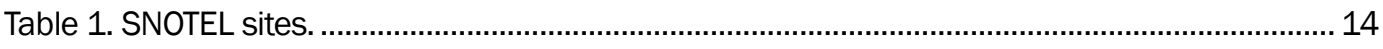

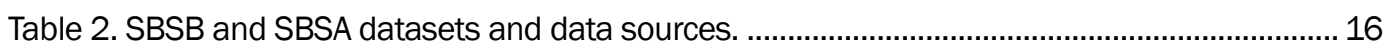

Table 3. Calibration parameter limits and units. ............................................................................ 18

Table 4. EB snow model calibration parameters. ...................................................................... 18

Table 5. HY snow model calibration parameters. ………......................................................... 18

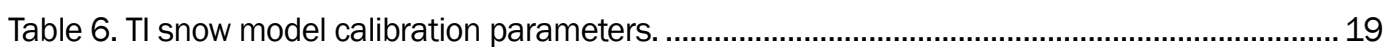

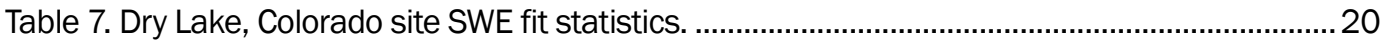

Table 8. Lost Horse, Washington site SWE fit statistics................................................................ 20

Table 9. Madison Butte, Oregon site SWE fit statistics................................................................. 21

Table 10. Myrtle Creek, Idaho site SWE fit statistics.......................................................................... 21

Table 11. Sierra Blanca, New Mexico site SWE fit statistics. ............................................................. 21

Table 12. Sheldon, Nevada site SWE fit statistics........................................................................ 21

Table 13. Hagan's Meadow, California site SWE fit statistics........................................................... 22

Table 14. Swamp Angel, Colorado site SWE fit statistics. ............................................................... 22

Table 15. Senator Beck Basin, Colorado site SWE fit statistics........................................................ 22 


\section{Preface}

This report describes the procedures and results from a study to improve the accuracy of snow accumulation and melting process simulation within the Gridded Surface Subsurface Hydrologic Analysis (GSSHA) model. The study was conducted from October 2011 to September 2012.

This study was conducted for the Flood and Coastal Storm Damage Reduction Research and Development Program under "Enhancing the Snowmelt Routines within GSSHA.” The Program Manager was Dr. Cary A. Talbot.

The work was performed by Michael L. Follum and Dr. Charles W. Downer, Hydrologic Systems Branch, (HSB), Flood and Storm Protection Division (FSPB), US Army Engineer Research and Development Center (ERDC) Coastal and Hydraulics Laboratory (CHL).

Dr. Aaron R. Byrd was Chief, HSB; Dr. Ty V. Wamsley was Chief, FSPD; and William R. Curtis was Technical Director, Flood and Coastal Storm Damage Reduction Research and Development Program. Jose E. Sanchez was Acting Director, CHL.

At the time of publication, COL Kevin J. Wilson was Commander of ERDC, and Dr. Jeffery P. Holland was Director. 


\section{Introduction}

The US Army Engineer Research and Development Center (ERDC) has a long history in developing and applying gridded physics-based models to help solve complex watershed-related issues. ERDC's Coastal and Hydraulics Laboratory (CHL) developed, and continues to further enhance, the capabilities of the continuous simulation, physics-based, spatially distributed, hydrologic model GSSHA. A simplistic energy balance method was originally employed by GSSHA for determining snow accumulation and melt. Applications of this method demonstrated both volume and timing errors for snow melt. This report outlines recent improvements made to the snow accumulation and melt routines within GSSHA to make it more applicable in snow-dominated regions.

Three methods are described in this report; original energy balance, hybrid energy balance, and temperature index. These are available within the GSSHA model to simulate snow accumulation and melt. By way of examples, how well these methods perform in terms of comparisons with observed data at several test sites in the western United States is shown. This report also shows how accounting for the temperature of the snowpack, known as heat deficit or cold content, can significantly improve the accuracy of the simulations.

\subsection{GSSHA model description}

GSSHA is a spatially-distributed, physics-based, continuous simulation hydrologic model. Computations in GSSHA are performed on a uniform raster grid, which is used to represent the modeled watershed system (Figure 1). Numerous hydrologic components - such as rainfall distribution, evapotranspiration (ET), infiltration, and snow melt/accumulation - are calculated within each grid cell of the model at a user-defined time step. Although these hydrologic components are calculated within each individual cell, they are connected through two-dimensional (2D) overland flow, 2D groundwater flow, and a one-dimensional stream network, which results in the overall watershed response. GSSHA also has the capacity to simulate interaction between surface water and groundwater through infiltration and connections between the stream network and the groundwater. 


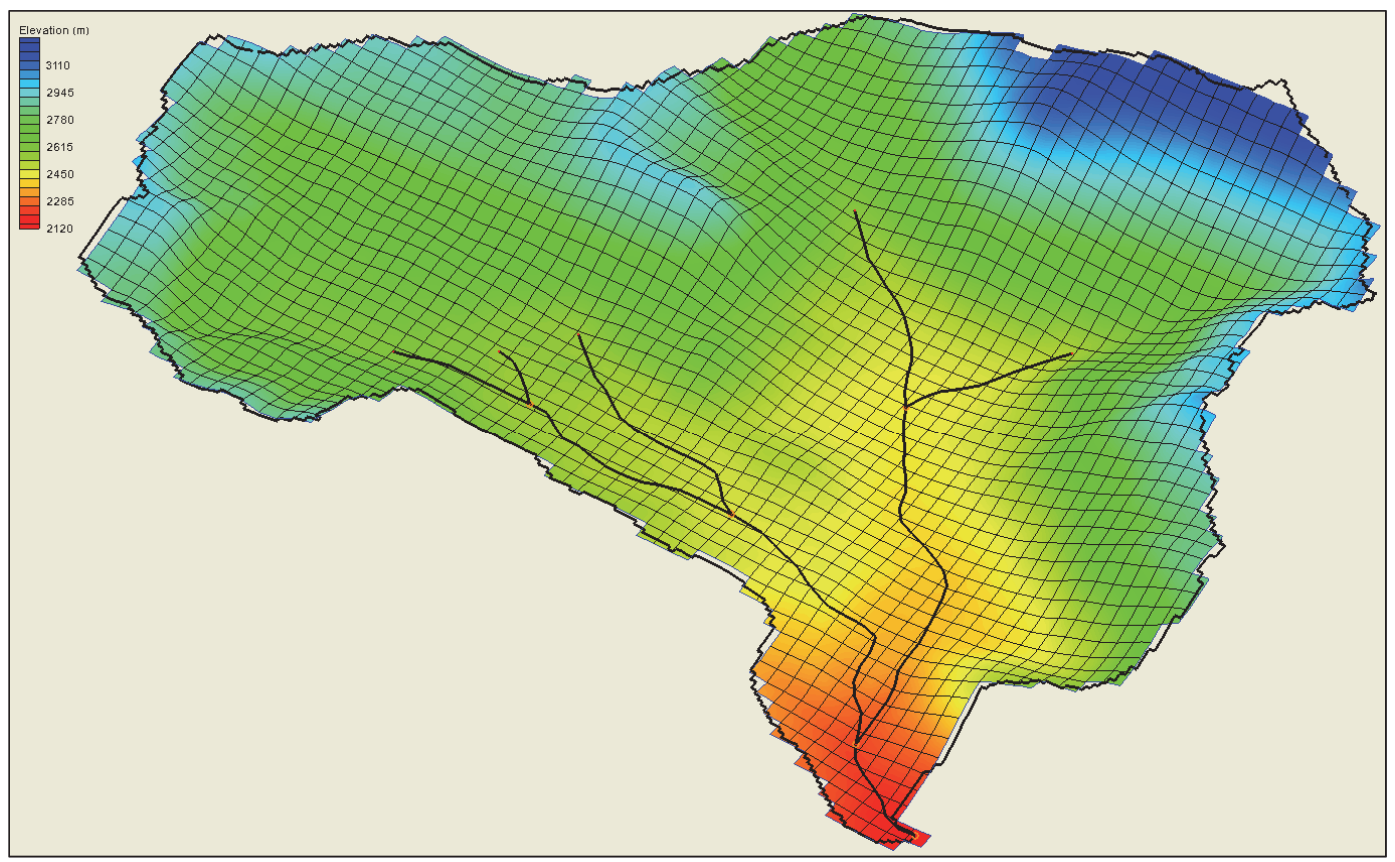

Figure 1. Structured grid format of the GSSHA Trout Creek river basin, California model (elevation in meters).

Hydrometeorology (HMET) data, as well as soil and land use characteristics, are unique to each individual grid cell, making the model useful in situations where uniform assumptions (i.e., the entire basin has the same land use characteristics, soil type characteristics, precipitation, etc.) are not realistic. Altering the snow accumulation and melt algorithms will change the way they are calculated within each grid cell, affecting them for the entire watershed.

In the original GSSHA snow accumulation and melt model, precipitation was assumed to be frozen when the air temperature was below $0^{\circ} \mathrm{C}$. Melting of the snow was assumed to occur when sufficient energy was transferred to the snowpack from a variety of sources: precipitation, sensible heat transfer due to turbulence, evaporation and sublimation, atmospheric longwave radiation, and longwave radiation emission by the soil. Because the energy balance formulation did not account for the subfreezing temperatures within the snowpack, it likely overestimated melt, therefore, underestimating the snowpack. Although the surface temperature might rise above $0{ }^{\circ} \mathrm{C}$, melting within the pack will not occur until the temperature of the snowpack rises above $0^{\circ} \mathrm{C}$. The heat that must be applied to bring the snowpack temperature to $0^{\circ} \mathrm{C}$ is referred to as the heat deficit. 


\subsection{Heat deficit}

The heat deficit, also referred to as cold content, is defined as the amount of heat that must be added to return the snowpack from below $0^{\circ} \mathrm{C}$ to an isothermal state $\left(\mathrm{o}^{\circ} \mathrm{C}\right)$ (Melloh 1999; Anderson 2006). The equations to calculate the heat deficit within this report are based on the National Weather Service River Forecasting System (NWSRFS) SNOW-17 model (Anderson 1973, 2006). SNOW-17 employs two factors that can increase or decrease the heat deficit: (1) energy flux between the snowpack and its surroundings, such as a temperature gradient between the atmospheric temperature and the antecedent temperature of the snowpack, and (2) mass change, such as precipitation. It is important to include the heat deficit because melt and rain continue to refreeze within the snow cover until the heat deficit reaches zero (Melloh 1999). The heat deficit described below is in units of millimeters of SWE, making it easily incorporated into most snow melt routines by simply reducing the amount of melt (in $\mathrm{mm}$ of SWE) calculated in the melt routine by the heat deficit.

\subsubsection{Energy flux heat deficit due to temperature gradients}

Temperature gradients between the atmosphere and the snowpack drive diffusion of heat within the snowpack, either increasing or decreasing the heat deficit. When the atmospheric temperature drops below the antecedent temperature of the snowpack, the snowpack temperature drops as well, increasing the temperature-caused heat deficit. When the atmospheric temperature rises above the antecedent temperature of the snowpack, the snow pack temperature gradually increases until it reaches $0{ }^{\circ} \mathrm{C}$, its maximum value. This increase in the snowpack temperature decreases the temperature-caused heat deficit until it reaches zero.

Ignoring the temperature deficit of the snow causes the simulated snow to melt too quickly when the air temperature rises from below $0{ }^{\circ} \mathrm{C}$ to above $0^{\circ} \mathrm{C}$. The $S N O W-17$ model incorporates a method for which temperature indices, essentially a term to consider the snowpack temperature, are calculated based on Equation 1, and then are used in Equation 2 to calculate the change in snow cover heat deficit due to temperature. Equations 1, 2, and 3 are used to account for the temperature deficit within the snowpack. The weighting multiplier (TIPM) and the proportionality factor $\left(N M_{F}\right)$ are calibration parameters, but results presented later in this report will show they are relatively insensitive, compared to the parameters and algorithms pertaining to the melting processes. 


$$
\begin{gathered}
A T I_{i}=A T I_{i-1}+\operatorname{TIPM}_{d t}\left(T_{a}-A T I_{i-1}\right) \\
\Delta D_{t}=N M_{F}\left(A T I_{i-1}-T_{a}\right) \\
T I P M_{d t}=1.0-(1.0-T I P M)^{d t / 6}
\end{gathered}
$$

where

$A T I_{i}=$ temperature indices at $i$ time step $\left({ }^{\circ} \mathrm{C}\right)$; at initial time step $A T I_{O}=0.0$

$T_{a}=$ air temperature $\left({ }^{\circ} \mathrm{C}\right)$

$d t=$ time step (hours)

$T I P M_{d t}=$ weighting multiplier (0.1 to 1.0) for previous time period

TIPM = weighting multiplier (0.1 to 1.0) for previous 6-hr period

$\Delta D_{t}=$ change in heat deficit due to a temperature gradient, expressed in water equivalent ( $\mathrm{mm} \mathrm{SWE}$ )

$N M_{F}=$ proportionality factor, also known as the negative melt factor $\left(\mathrm{mm} /{ }^{\circ} \mathrm{C}\right.$ per $\left.6 \mathrm{hr}\right)$

\subsubsection{Mass change heat deficit due to precipitation}

Like temperature discussed above, precipitation can also affect the heat deficit. Precipitation can increase or decrease the mass of the snowpack and depending on the temperature of the precipitation, can increase or decrease the heat deficit. Equation 4 is used to capture the precipitation portion of the heat deficit within the snow cover while precipitation is occurring. Continuous accounting of the heat deficit due to both temperature and precipitation is computed with Equation 5 .

$$
\begin{gathered}
\Delta D_{p}=\left(P_{n}{ }^{*} T_{p}\right) /\left(L_{f} / c_{i c e}\right) \\
D_{i}=D_{i-1}+\Delta D_{t}+\Delta D_{p}
\end{gathered}
$$

where

$$
\begin{aligned}
\Delta D_{p}= & \text { change in heat deficit due to precipitation, expressed in water } \\
& \text { equivalent (mm SWE) } \\
P_{n}= & \text { water equivalent of adjusted precipitation }(\mathrm{mm})(\text { see } \\
& \text { Section 2.1) }
\end{aligned}
$$


$T_{p}=$ temperature of snowfall; assumed equal to air temperature or $0{ }^{\circ} \mathrm{C}$, whichever is less $\left({ }^{\circ} \mathrm{C}\right)$

$L_{f}=$ latent heat of fusion $\left(80 \mathrm{cal}^{*} \mathrm{gm}^{-1}\right)$

$c_{\text {ice }}=$ specific heat of ice $\left(0.5 \mathrm{cal}^{*} \mathrm{gm}^{-1 *}{ }^{\circ} \mathrm{C}^{-1}\right)$

$D_{i}=$ heat deficit of snowpack during $i$ time step, expressed in water equivalent (mm SWE); at initial time step $D_{o}=0.0$ 


\section{Description of the Snow Accumulation and Melt Methods}

All three methods used within GSSHA to simulate snow melt (energy balance, hybrid energy balance, and temperature-index) assume the snowpack consists of a single layer. Certain capabilities such as time variations of liquid water content (Blöschl and Kirnbauer 1991), interflow within the snowpack layers due to ice sheets, and avalanche modeling (Colbeck 1991) do exist when applying multi-layer snowpack models; but the required data to apply such models at the watershed scale is unrealistic in most basins. Multi-layer snow models are typically deployed at the sitescale where spatially close data are available, making them impractical in many sparse-data cases.

In nature, snow accumulation and melt are part of a distributed process. Due to the spatially distributed structure of the GSSHA model, the snow is modeled as a distributed process that gives it more potential for addressing a variety of real-world problems rather than a semi-distributed or lumped-parameter hydrologic model (Kimbauer et al. 1994).

\subsection{Snow accumulation}

Independent of the three melt methods, GSSHA has a means to account for inaccuracies in the gauge systems as well as the temperature at which snow begins to form. Typically, when the air temperature is at or below $\mathrm{O}^{\circ} \mathrm{C}$, precipitation falls in the form of snow. However, due to temperature differences at snow formation height (i.e. temperature in the upper atmosphere where snow forms may be lower than the ground temperature), snow can form when the air surface temperatures are greater than $\mathrm{O}^{\circ} \mathrm{C}$. For this reason, the temperature at which precipitation begins to fall as snow $\left(M B A S E, \mathrm{O}^{\circ} \mathrm{C}\right)$ is considered a global calibration parameter. During precipitation, when the air temperature is below MBASE, land surface accumulation is assumed to be snow or ice. If snow is already present in a cell, the accumulation is added to the existing snow.

Due to measure catch deficiencies, precipitation gauges often underestimate the amount fallen in the form of snow (Anderson 2006). As a result, the snow adjustment factor $(S C F)$ is applied to the gauge measurement of 
precipitation $\left(P_{x}\right)$ to create the adjusted precipitation of the newly fallen snow $\left(P_{n}\right)$ (see Equation 6). SCF is considered a calibration parameter, while the fraction of precipitation in the form of snow $\left(f_{s}\right)$ is considered constant at 1.0 when temperatures are at or below MBASE, and 0.0 when above $M B A S E$. This in effect causes the model to treat partially frozen precipitation such as frozen rain, commonly referred to as "slush" or "sleet," as snow or rain, depending on the temperature and $M B A S E$.

By not deciphering when precipitation is in the form of frozen rain, the snowpack, under specialized circumstances, might be slightly overestimated in the beginning stages. For example, if frozen rain occurs when there is not a snowpack, the model could simulate the frozen rain as snow and form a snowpack, when in reality none are formed. If a snowpack already exists during a frozen rain event, there will be no effect on the snow simulation because the temperature and volume of the snowpack and precipitation are the only factors that contribute to the increase or decrease of the snowpack; whether the precipitation is in the form of snow, rain, or frozen rain makes no difference (Section 2.2). Any errors associated with the assumption that precipitation is in the form of snow or rain will be infrequent and small due to the rarity of occurrences (frozen rain simulated as snow when no previous snowpack exists) and relatively small volumes of precipitation during these occurrences.

$$
P_{n}=P_{x}^{*} f_{s}^{*} S C F
$$

where

$$
\begin{aligned}
P_{x} & =\text { gauge measurement of water equivalent of precipitation }(\mathrm{mm}) \\
f_{s} & =\text { fraction of precipitation in the form of snow } \\
S C F & =\text { snow adjustment factor (unitless) }
\end{aligned}
$$

\subsection{Snow melt}

\subsubsection{Energy balance (EB) method}

The energy balance (EB) method of estimating snow melt uses a simple conceptualization of the snowpack (Downer and Ogden 2006). This method calculates the total energy, (cal cm${ }^{-2} \mathrm{hr}^{-1}$ ), available hourly to melt snow based on energy fluxes due to:

1. Evaporation and sublimation $\left(Q_{e}\right.$, Equations 7 and 8); 
2. Sensible heat transfer due to turbulence ( $Q_{h}$, Equation 9);

3. Atmospheric longwave radiation ( $Q_{a}$, Equation 10);

4. Longwave emission by soil (constant, $Q_{b s}=27.0$ ); and

5. Precipitation ( $Q_{p}$, Equation 11)

*all energy fluxes, (Q), are in units of: cal $\mathrm{cm}^{-2} \mathrm{hr}^{-1}$

$$
\begin{gathered}
f(V)=0.0002 * U \\
Q_{e}=f(V) * \frac{r h}{100} * e_{s}-6.11 \\
Q_{h}=0.366 * T_{a}^{*} P_{a}^{*} f(V) \\
Q_{a}=49.56 \times 10^{-10 *}\left(T_{a}+273\right)^{4} \\
Q_{p}=\frac{P_{n}{ }^{*} T_{a}}{100}
\end{gathered}
$$

where

$$
\begin{aligned}
f(V) & =\text { wind function }\left(\mathrm{km} \mathrm{hr}^{-1}\right)(\text { Anderson } 1978) \\
U & =\text { wind speed }\left(\mathrm{m} \mathrm{s}^{-1}\right) \\
r h & =\text { relative humidity }(\%) \\
e_{\text {sat }} & =\text { saturated vapor pressure }(\mathrm{mb}) \\
P_{a} & =\text { atmospheric pressure }(\mathrm{mb})
\end{aligned}
$$

Equation 12 calculates the total energy to melt snow using these energy fluxes. The latent heat of melting, $\left(\sim 80 \mathrm{cal} \mathrm{cm}^{-3}\right)$, is then used to calculate the melted water (Equation 13).

$$
\begin{gathered}
Q_{\text {melt }}=Q_{a}-Q_{b s}+Q_{e}+Q_{h}+Q_{p} \\
M_{E B}=\frac{\left(Q_{\text {melt }} / 100\right)}{80.0} * d t
\end{gathered}
$$

where

$$
Q_{\text {melt }}=\text { total energy available to melt snow }\left(\mathrm{cal} \mathrm{cm}^{-2} \mathrm{hr}^{-1}\right)
$$




\section{$M_{E B}=$ melt calculated using energy balance snow melt routine (mm SWE)}

The EB method of estimating snowfall accumulation and melting does not include any representation of the snowpack's temperature. This method also assumes a constant soil temperature, resulting in a constant value for longwave emission by the soil $\left(Q_{b s}=27.0 \mathrm{cal} \mathrm{cm}^{-1} \mathrm{hr}^{-1}\right)$. Future work efforts might look at calculating this value, but a soil temperature model is required. More information on the methods and equations (Equations 7 through 13) used to calculate the energy fluxes in this method can be found on the GSSHA Wiki site (http://www.gsshawiki.com).

\subsubsection{Temperature-index (TI) method}

The temperature-index (TI) method of estimating snow melt is based on the NWSRFS SNOW-17 model. This method takes into consideration the time of year, melt due to temperature, melt due to precipitation, and heat deficits within the snowpack. Equations 14 and 15 are used to calculate the amount of melt during a time step. Equation 14 is used in precipitationdominated time spans when the average precipitation over the previous 6 hours has exceeded $0.25 \mathrm{~mm} \mathrm{hr}^{-1}$ and precipitation is occurring during the current time step. Equation 15 is used when the melt is considered temperature-dominated. The precipitation temperature, $T_{r}$, is assumed to be $\mathrm{o}^{\circ} \mathrm{C}$ or the temperature of the air, whichever is greater. Both melt routines work only when the air surface temperature is greater than $0^{\circ} \mathrm{C}$ and only one melt routine is run per time step.

This method also keeps track of melt water being stored and water being released from the snowpack. Although Equations 1 through 5 help simulate the ripeness of the snowpack by accounting for the heat deficit, Equations 18 through 21 are included in the TI method to help determine how much liquid water is being stored within the snowpack. The amount of melt that leaves the snowpack $\left(M_{T I}\right)$ is calculated in Equation 20 and is representative of the overall melt from the pack after the heat deficit and water storage capacity are accounted for.

$$
\begin{aligned}
& M_{r}=\sigma^{*} d t *\left[\left(T_{a}+273\right)^{4}-273^{4}\right]+0.0125 * P_{x}^{*}{ }^{*} r_{u s e}{ }^{*} T_{r}+ \\
& 8.5^{*} \text { fua }{ }^{*}(d t / 6) *\left[\left(0.9 * e_{\text {sat }}-6.11\right)+0.00057^{*} P_{a}{ }^{*} T_{a}\right.
\end{aligned}
$$




$$
\begin{gathered}
M_{n r}=M_{f}{ }^{*}\left(T_{a}-M B A S E\right)+0.0125 * P_{x}{ }^{*} f r_{u s e}{ }^{*} T_{r} \\
M_{f}=(d t / 6) *\left[S_{v}{ }^{*} A_{v}{ }^{*}\left(M F_{M A X}-M F_{M I N}\right)+M F_{M I N}\right] \\
S_{v}=0.5 * \sin \left(\frac{N^{*} 2 * \pi}{366}\right)+0.5 \\
W_{q x}=P L W H C^{*} W_{i} \\
Q_{w}=M_{r}+M_{n r}+P_{x}{ }^{*} f r_{u s e} \\
M_{T I}=Q_{w}+W_{q, n}-W_{q x}-D 2-\left(P L W H C C^{*} D 2\right) \\
W_{q, n+1}=W_{q, n}-Q_{w}-D 2
\end{gathered}
$$

where

$$
\begin{aligned}
M_{r} & =\text { melt during precipitation-dominated time steps }(\mathrm{mm}) \\
\sigma & =\text { Stefan-Boltzman constant }\left(6.12^{*} 10^{-10} \mathrm{~mm} /{ }^{\circ} \mathrm{K} / \mathrm{hr}\right) \\
f r_{u s e} & =\text { fraction of precipitation in the form of rain } \\
f u a & =\text { average wind function }(\mathrm{mm} / \mathrm{mb} \text { per } 6 \mathrm{hr}) \\
M_{n r} & =\text { melt during temperature-dominated time steps }(\mathrm{mm}) \\
M_{f} & =\text { melt factor }\left(\mathrm{mm} /{ }^{\circ} \mathrm{C} / \mathrm{dt}\right) \\
M F_{M I N} & =\text { minimum melt factor on }- \text { Dec } 21\left(\mathrm{~mm} \mathrm{SWE} /{ }^{\circ} \mathrm{C} \text { per } 6 \mathrm{hr}\right) \\
M F_{M A X} & =\text { maximum melt factor on }-\mathrm{June} 21\left(\mathrm{~mm} \mathrm{SWE} /{ }^{\circ} \mathrm{C} \text { per } 6 \mathrm{hr}\right) \\
M B A S E & =\text { temperature at which precipitation begins to fall as snow }\left({ }^{\circ} \mathrm{C}\right) \\
A_{v} & =\text { seasonal variation adjustment } \\
S_{v} & =\text { seasonal sine curve melt variation } \\
N & =\text { day number since March } 21 \\
M_{T I} & =\text { overall melt calculated using the temperature-index snow melt } \\
& \text { routine (mm SWE) } \\
W_{q x}= & \text { liquid water capacity (mm) } \\
W_{q} & =\text { liquid water held by the snow (mm) } \\
W_{i} & =\text { water equivalent of the ice portion of the snow cover }(\mathrm{mm}) \\
Q_{w} & =\text { liquid water available at the snow surface }(\text { mm }) \\
P L W H C & =\text { percent liquid water holding capacity (decimal fraction) }
\end{aligned}
$$

The ice portion of the snowpack $\left(W_{i}\right)$ is calculated based on the SWE and $P L W H C$ of the snowpack. The calibration parameters for the TI method include: SCF, $M F_{M A X}, M F_{M I N}$, fua, MBASE, fruse, TIPM, NMF, and PLWHC. 
For more information on the $S N O W-17$ model and the equations presented (14 through 21), the reader is guided to Anderson (1973 and 2006) and Melloh (1999). The SNOW-17 model was intended for a 6-hr time step, but is compatible with an hourly time step. Although GSSHA employs a global variable time step, which can be sub-minute, the TI method is run hourly. The melt generated during the hour time step is distributed to the other GSSHA model processes at the global variable time step.

\subsubsection{Hybrid energy balance (HY) method}

A simple adjustment to the EB method was made to create the hybrid energy balance (HY) method for snow melt. By accounting for the heat deficit within the melting algorithms of the EB method, the melting processes and the snow pack dynamics (in the form of heat deficit) are accounted for, making the model more accurate. Equation 22 shows the simple adjustment that creates the $H Y$ method. Equations 1 through 5 show how the heat deficit is calculated. The HY method requires few, if any, calibration parameters because the EB method does not have any and the calibration parameters associated with the heat deficit equations are relatively insensitive. Although GSSHA uses a global variable time step, which can be sub-minute, the heat deficit is calculated at an hourly time step. Therefore, the HY method is also run at an hourly time step. The melt generated during the hourly time step is distributed to the other GSSHA model processes at the global variable time step.

$$
M_{H Y}=M_{E B}-D 2
$$

where

$M_{H Y}=$ melt calculated using hybrid snow melt routine (mm SWE) 


\section{Snow Depth and Density Modeling}

Snow depth and density are simulated in GSSHA independently of the melting algorithm used. They are calculated hourly using routines taken from the SNAP model (Albert and Krajeski 1998) and incorporated within GSSHA as subroutines. Information related to SWE, snow depth, density, snow saturation, effective porosity, and hydraulic conductivity are exchanged among GSSHA and the SNAP subroutines. GSSHA simulates the SWE, while the SNAP subroutines simulate the remaining parameters. More information on the connections between GSSHA and SNAP and how these connections improve the vertical and lateral flow simulation within the snow pack will be discussed in an upcoming report on melt-water transport within GSSHA.

Albert and Krajeski (1998) state the following in regard to snow depth calculations in the SNAP model:

"The snow depth prediction equations are based on the form of Anderson (1973), which are also used by Jordan (1991). New snow is calculated from precipitation input data. For snow settlement the model predicts the rate of densification, calculates the overburden and adjusts the snow depth accordingly."

Jordan (1991) refers to the SNow THERMal (SNTHERM) model (Jordan 1991 and 1998), often regarded as one of the most advanced energy balance snow models available.

The snow density calculated by the SNAP subroutines changes in response to snow accumulation, settlement, and melt, and is computed with the snow depth predictions or as updated by the user (Albert and Krajeski 1998). GSSHA currently does not allow the user to update the snow density as a calibration parameter, leaving it to be calculated based on the snow depth predictions of the SNAP subroutines. Because of this, the SNAP subroutines do not have calibrated parameters while running within GSSHA.

For more information on the SNAP model, consult Albert and Krajeski (1998). For more information on the depth prediction equations used within the SNAP subroutines, consult Anderson (1973) and Jordan (1991; 1998). 


\section{Code Validation}

In GSSHA, snow accumulation and melt are calculated on a cell-by-cell basis. The GSSHA model, in relation to the snow processes, is essentially a mosaic of point models. Therefore, to test and compare GSSHA's original and new snow modeling capabilities, several point location models were developed to test the snow accumulation and melt algorithms that GSSHA now employs in each cell. By capturing snow accumulation melt at the point scale accurately, the entire watershed snow accumulation and melt processes of the snowpack are tested.

\subsection{Data collection}

Data associated with nine sites in the western United States were collected to support several test cases wherein GSSHA model simulated output from the three snow accumulation and melt methods were compared with their observed counterparts. Simulated snow depth was also compared with observed snow depth data at two sites at the Senator Beck Basin study area in Colorado.

Input meteorological data requirements for the EB and HY methods include hourly precipitation, temperature, pressure, relative humidity, and wind speed data. The TI method requires only hourly temperature and precipitation data. Observed meteorological and snow data were collected from seven snow telemetry (SNOTEL) sites (NWCC 2010), three study plots within the Senator Beck Basin study area, and the Lake Tahoe, California airport (Figure 2). The data collected from each site were used to compare simulated SWE results with their observed counterparts and to force the GSSHA point snow models. At two locations within the Senator Beck Basin study area simulated snow depth was compared to the observed data.

\subsubsection{SNOTEL sites}

SNOTEL sites across the western United States were investigated to determine whether they had the necessary data to test the different snow routines. Six SNOTEL sites were selected for model testing. An additional site in the Trout Creek Basin (TCB), Hagan Meadows, California, was also chosen because it, along with the HMET data from the nearby Lake Tahoe 


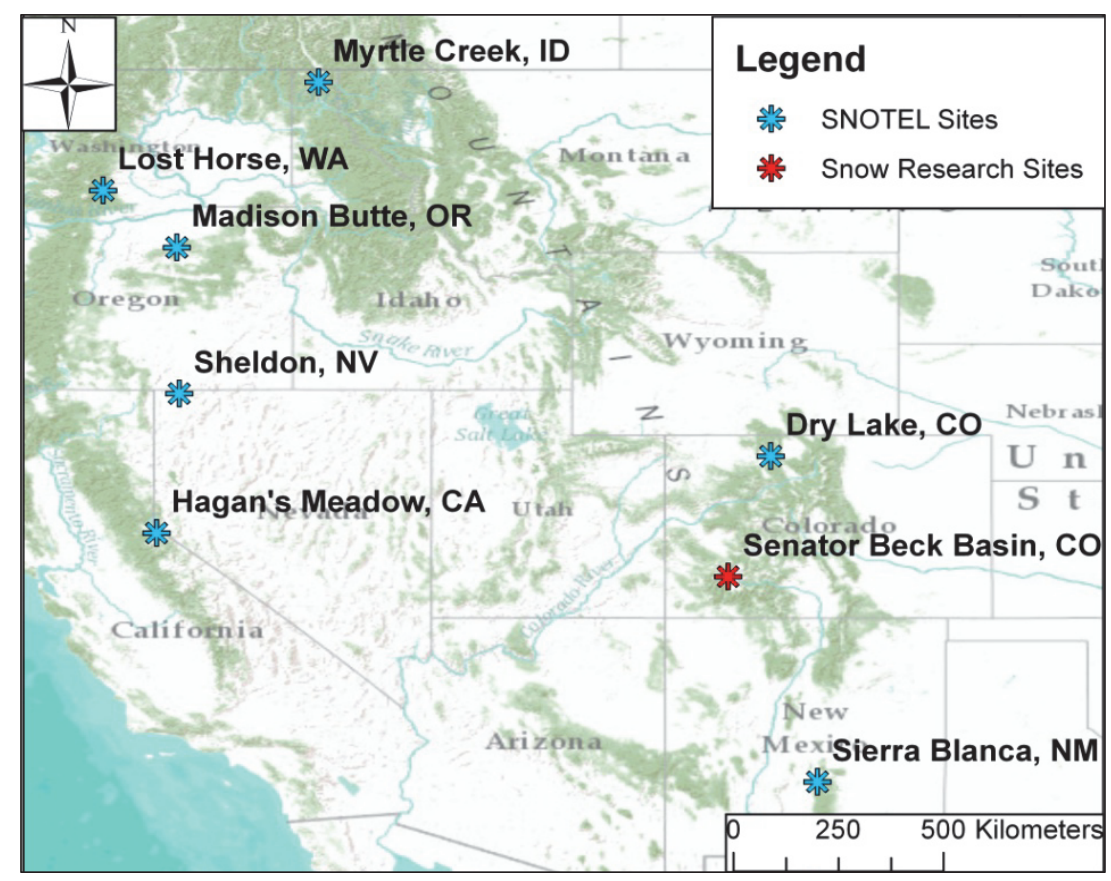

Figure 2. Collected data locations.

airport, had the required data to analyze model-to-measurement misfit. Table 1 shows the SNOTEL site name, abbreviation, elevation, and timeframe of the data collected from each site.

Table 1. SNOTEL sites.

\begin{tabular}{|l|l|l|l|l|}
\hline Site Name & Abbreviation & Elevation $(\mathrm{m})$ & Start Date & End Date \\
\hline Sheldon, NV & SH & 1786 & $10 / 01 / 2000$ & $07 / 20 / 2010$ \\
\hline Sierra Blanca, NM & SB & 3133 & $10 / 01 / 2004$ & $12 / 06 / 2005$ \\
\hline Myrtle Creek, ID & MC & 1073 & $10 / 01 / 2005$ & $08 / 13 / 2009$ \\
\hline Madison Butte, OR & MB & 1570 & $10 / 01 / 2005$ & $07 / 20 / 2010$ \\
\hline Lost Horse, WA & LH & 1561 & $10 / 01 / 2003$ & $07 / 20 / 2010$ \\
\hline Dry Lake, CO & DL & 2560 & $10 / 01 / 2003$ & $07 / 21 / 2010$ \\
\hline Hagan Meadows, CA & TCB & 2370 & $01 / 01 / 2000$ & $09 / 30 / 2009$ \\
\hline
\end{tabular}

\subsubsection{Lake Tahoe airport data}

Because the Hagan's Meadow SNOTEL site was not equipped with the correct sensors to measure the pressure, relative humidity, wind speed, and radiation data, these data were collected from the Lake Tahoe airport (Figure 3) via the US Air Force 14 ${ }^{\text {th }}$ Weather Squadron. The airport data were collected at an elevation of 1,911-m from January 1, 2000, to September 30, 2009. 


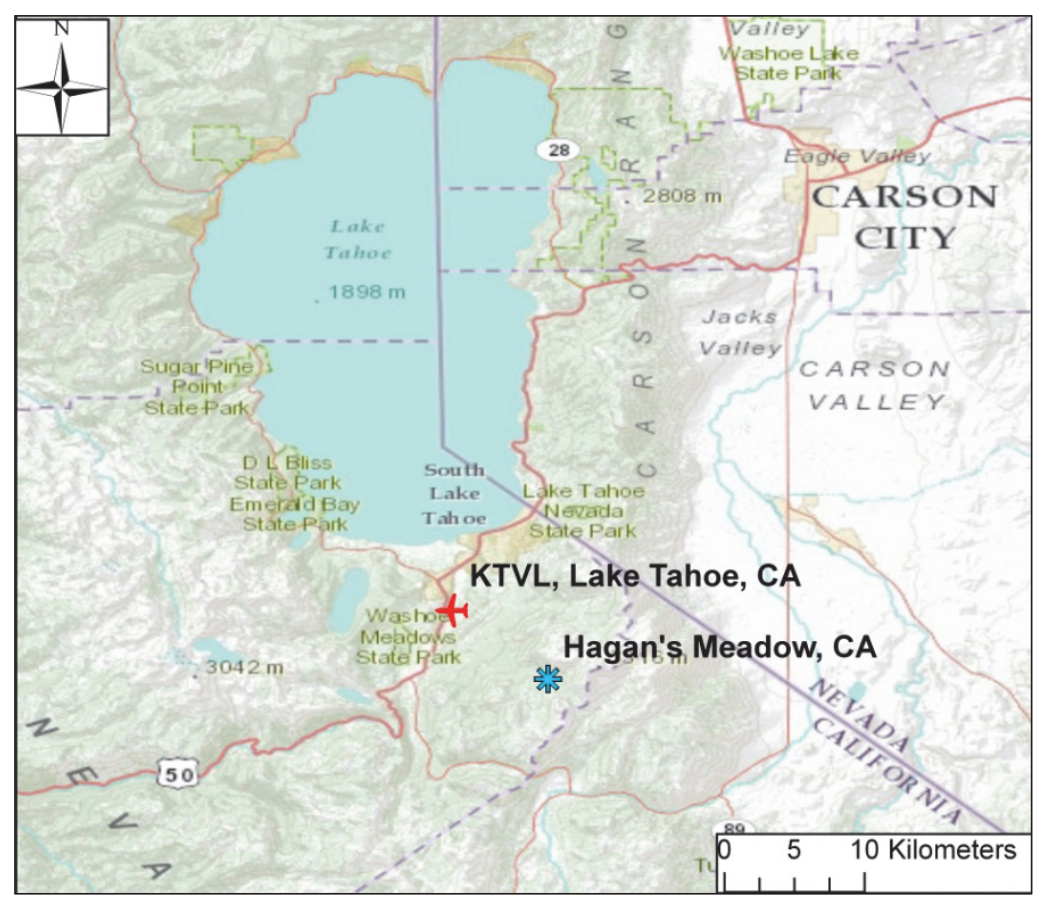

Figure 3. Hagan's Meadow and Lake Tahoe airport locations.

Although having HMET data collected from two sites (KTVL and Hagan's Meadow SNOTEL) is not preferred, this is representative of a typical modeling scenario in which data are collected from numerous sources. The distance between the airport and the Hagan's Meadow SNOTEL site $(\sim 7.3 \mathrm{~km})$ and the difference in elevation between the airport and the Hagan's Meadow SNOTEL site $(\sim 0.5 \mathrm{~km})$ are both significant, but as previously mentioned, represent a typical modeling scenario.

\subsubsection{Senator Beck Basin study area data}

The Senator Beck Basin study area (Figure 4) is in the Ouray Ranger District of the Uncompahgre National Forest in the western San Juan Mountains of southwestern Colorado (www.snowstudies.org). Three study plots are within or near the roughly 1 square mile basin: Putney, Swamp Angel, and Senator Beck Basin Study Sites. Using hourly data from all three sites, input HMET data files were created that represent the Swamp Angel (SBSA) and Senator Beck Basin Study Site (SBSB). Staff at the Center for Snow and Avalanche Studies approximately 15 times per year measured the SWE, snow depth (SD), and snow density at SBSA and SBSB. Table 2 shows which study plot datasets were used to create the SBSB and SBSA datasets. Senator Beck Basin study area data was collected from October, 1 2006, through June 24, 2010. 


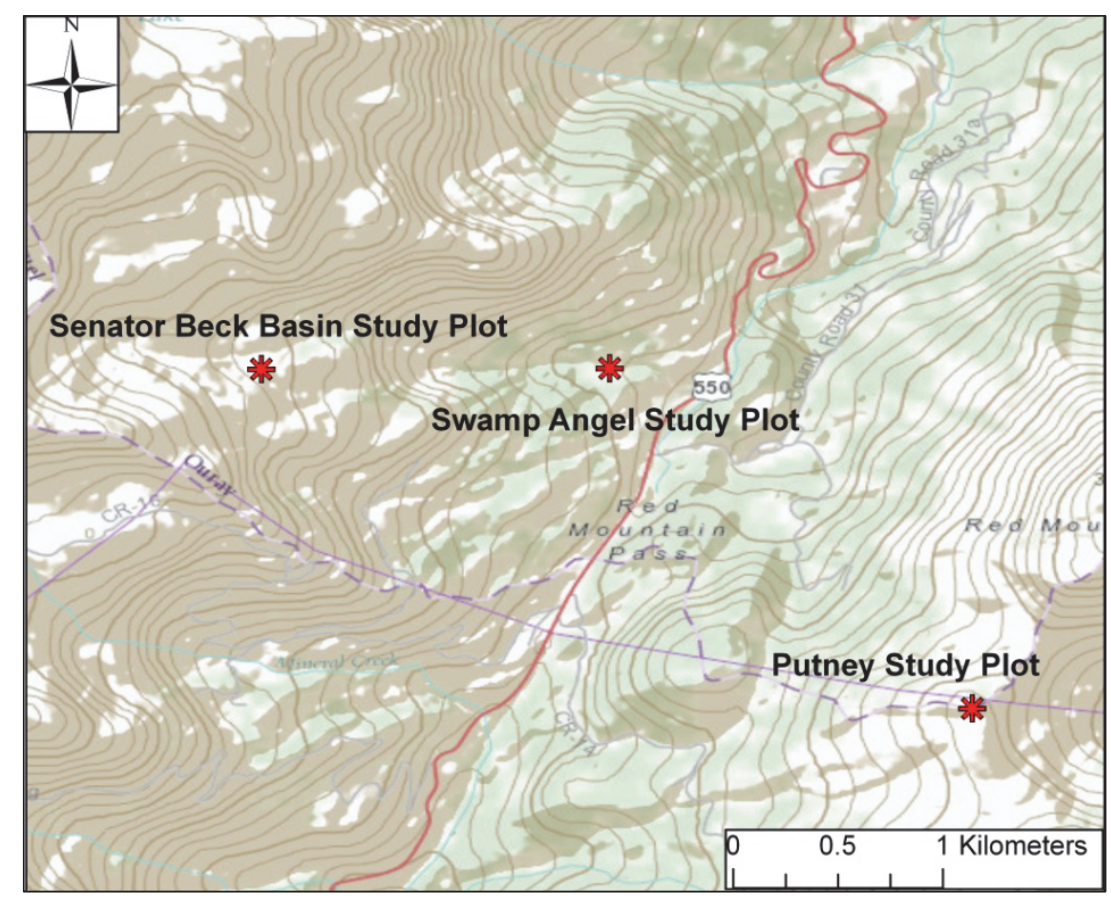

Figure 4. Senator Beck Basin, Colorado.

Table 2. SBSB and SBSA datasets and data sources.

\begin{tabular}{|l|l|l|}
\hline & SBSB Dataset & SBSA Dataset \\
\hline Temperature & B & C \\
\hline Precipitation & C & C \\
\hline Relative Humidity & A & A \\
\hline Pressure & C & C \\
\hline Wind Speed & A & A \\
\hline Snow Water Equivalent & B & C \\
\hline Snow Depth & B & C \\
\hline Snow Density & B & C \\
\hline
\end{tabular}

A - Data came from Putney Study Plot (3756-m)

B - Data came from Senator Beck Basin Study Plot (3714-m)

C - Data came from Swamp Angel Study Plot (3371-m)

\subsection{Metrics}

Accuracy among the snow melt models is quantified by comparing the Nash-Sutcliffe efficiency (NSE, Equation 23) (Nash and Sutcliffe 1970), root mean square error (RMSE, Equation 24), and mean absolute error (MAE, Equation 25). The observed and simulated data were compared for the entirety of the simulation, and for all snow events combined 
sequentially. One snow event was defined per water year (o1 Oct through 31 Sept), and was defined as the largest period with continuously observed snow. Analysis of snow events was carried out to not bias the results with numerous snowless days.

$$
\begin{gathered}
N S E=1-\frac{\sum_{t=1}^{T}\left(Q_{0}^{t}-Q_{m}^{t}\right)^{2}}{\sum_{t=1}^{T}\left(Q_{0}^{t}-\bar{Q}_{0}\right)^{2}} \\
R M S E=\sqrt{\frac{\sum_{t=1}^{T}\left(Q_{0}^{t}-Q_{m}^{t}\right)^{2}}{T-1}} \\
M A E=\frac{1}{T} \sum_{t=1}^{T}\left|Q_{t=1}^{T}-Q_{m}^{t}\right|
\end{gathered}
$$

where

$$
\begin{aligned}
N S E & =\text { efficiency of simulation } \\
R M S E & =\text { root mean square error of simulation } \\
M A E & =\text { mean absolute error of simulation } \\
T & =\text { time span of period of interest } \\
t & =\text { time step within time span, } T \\
Q_{0}^{t} & =\text { observed value at time } t \\
Q_{m}^{t} & =\text { modeled value at time } t \\
\overline{Q_{0}} & =\text { average observed value over time span, } T
\end{aligned}
$$

\subsection{Calibration of the snow models}

The EB model requires two total calibration parameters - the snow adjustment factor $(S C F)$, which accounts for misreadings in precipitation of the gauge system, and the temperature at which precipitation begins to fall in the form of snow (MBASE). The HY model requires four total calibrated parameters, two associated with the snow accumulation (SCF and MBASE), and two associated with the heat deficit (TIPM and $N M_{F}$ ). The TI model requires nine total calibrated parameters associated with snow accumulation, heat deficit, melt, and water distribution within the snowpack. These calibrated parameters are in Section 2.2. All three snow models were calibrated using observed SWE data. The PEST model (Doherty et al. 2002) was used to calibrate the snow models, and the lower and upper limits used for each parameter are in Table 3. The calibrated parameters for the EB, 
HY, and TI snow models are in Tables 4, 5, and 6, respectively. Based on the PEST calibration of forward model calls, the EB method is most sensitive to $S C F$; the HY method is most sensitive to TIPM and $N M_{F}$, and the TI method is most sensitive to $M F_{M I N}$ and $S C F$.

Table 3. Calibration parameter limits and units.

\begin{tabular}{|c|c|c|c|c|}
\hline $\begin{array}{l}\text { Calibration } \\
\text { Parameter }\end{array}$ & Description & Lower Limit & Upper Limit & Units \\
\hline MF & maximum melt factor & $0.00^{1}$ & $2.50^{1}$ & $\left(\mathrm{~mm} \cdot{ }^{\circ} \mathrm{C}^{-1} \cdot 6-\mathrm{hr} r^{-1}\right)$ \\
\hline$M F_{M I N}$ & minimum melt factor & $0.00^{1}$ & $1.00^{1}$ & $\left(\mathrm{~mm} \cdot{ }^{\circ} \mathrm{C}^{-1} \cdot 6-\mathrm{hr} r^{-1}\right)$ \\
\hline fruse & fraction of precipitation as rain & $0.00^{\circ}$ & $1.00^{\circ}$ & unitless \\
\hline SCF & snow adjustment factor & $0.80^{\circ}$ & $1.20^{\circ}$ & unitless \\
\hline TIPM & weighting factor for heat deficit & $0.01^{1}$ & $1.00^{1}$ & unitless \\
\hline$N M_{F}$ & negative melt factor & $0.00^{\circ}$ & $1.00^{\circ}$ & $\left(m m^{\circ}{ }^{\circ} \mathrm{C}^{-1} \cdot 6-h r^{-1}\right)$. \\
\hline fua & average wind function & $0.00^{\circ}$ & $1.00^{\circ}$ & $\left(m m \cdot m b^{-1} \cdot 6-h r^{-1}\right)$ \\
\hline PLWHC & $\begin{array}{l}\text { percent liquid water holding } \\
\text { capacity }\end{array}$ & $0.00^{1}$ & $0.40^{1}$ & unitless \\
\hline MBASE & $\begin{array}{l}\text { temperature at which } \\
\text { precipitation begins to fall as } \\
\text { snow }\end{array}$ & $0.00^{2}$ & $5.00^{2}$ & ${ }^{\circ} \mathrm{C}$ \\
\hline
\end{tabular}

oPhysical limits of parameters or based on previous calibration exercises

${ }^{1}$ Snow accumulation and ablation model - Snow-17 (Anderson 2006)

${ }^{2}$ National snow and ice data center website (NSIDC 2012)

Table 4. EB snow model calibration parameters.

\begin{tabular}{|l|l|l|l|l|l|l|l|l|l|}
\hline & DL & LH & MB & MC & SB & SH & TCB & SBSA & SBSB \\
\hline SCF & 1.20 & 1.20 & 1.20 & 1.20 & 1.20 & 1.20 & 1.20 & 1.20 & 1.04 \\
\hline MBASE & 4.02 & 4.05 & 4.11 & 4.82 & 3.79 & 4.12 & 4.00 & 4.00 & 4.00 \\
\hline
\end{tabular}

* most sensitive parameter highlighted

DL - Dry Lake, CO LH - Lost Horse, WA MB - Madison Butte, OR MC - Myrtle Creek, ID SB - Sierra Blanca, NM SH - Sheldon, NV TCB - Hagan's Meadow, CA SBSA - Swamp Angel Study Site, CO SBSB - Senator Beck Basin Study Site, CO

Table 5. HY snow model calibration parameters.

\begin{tabular}{|l|l|l|l|l|l|l|l|l|l|}
\hline & DL & LH & MB & MC & SB & SH & TCB & SBSA & SBSB \\
\hline SCF & 1.07 & 1.19 & 1.20 & 0.80 & 1.03 & 0.88 & 0.98 & 1.20 & 0.83 \\
\hline TIPM & 0.00 & 0.00 & 0.21 & 0.01 & 0.29 & 0.10 & 0.00 & 0.30 & 0.02 \\
\hline NMF $_{F}$ & 0.17 & 0.17 & 0.55 & 0.53 & 0.42 & 0.37 & 0.58 & 0.28 & 0.18 \\
\hline MBASE & 3.98 & 4.12 & 3.17 & 4.23 & 3.74 & 3.80 & 4.00 & 4.00 & 4.00 \\
\hline
\end{tabular}

*two most sensitive parameters highlighted 
Table 6. TI snow model calibration parameters.

\begin{tabular}{|l|l|l|l|l|l|l|l|l|l|}
\hline & DL & LH & MB & MC & SB & SH & TCB & SBSA & SBSB \\
\hline MF $_{\text {MAX }}$ & 0.56 & 0.60 & 0.57 & 0.52 & 0.57 & 0.12 & 0.70 & 0.55 & 0.77 \\
\hline MF $_{\text {MIN }}$ & 0.01 & 0.00 & 0.01 & 0.02 & 0.00 & 0.10 & 0.00 & 0.01 & 0.00 \\
\hline fruse & 0.00 & 0.00 & 0.02 & 0.00 & 0.03 & 0.28 & 0.01 & 0.01 & 0.00 \\
\hline SCF & 1.00 & 1.00 & 1.02 & 0.94 & 1.01 & 0.80 & 0.92 & 1.00 & 0.80 \\
\hline TIPM & 0.00 & 0.36 & 0.00 & 0.00 & 0.28 & 1.00 & 0.00 & 0.20 & 0.24 \\
\hline NMF & 0.18 & 0.34 & 0.25 & 0.05 & 0.23 & 0.00 & 1.00 & 0.20 & 0.26 \\
\hline fua & 0.90 & 0.90 & 0.90 & 0.90 & 0.90 & 0.11 & 0.90 & 0.18 & 0.11 \\
\hline PLWHC & 0.16 & 0.29 & 0.22 & 0.00 & 0.15 & 0.01 & 0.40 & 0.20 & 0.10 \\
\hline MBASE & 4.00 & 3.97 & 3.98 & 4.05 & 3.95 & 4.27 & 4.00 & 4.00 & 4.00 \\
\hline
\end{tabular}

*three most sensitive parameters highlighted 


\section{Results}

The EB, HY, and TI snow models were evaluated using observed SWE data. As discussed in Section 4.2, the simulations were compared for the entire simulation (Overall) and each major snow event for each water year (Events). Because SBSA and SBSB datasets have periodic observations (approximately 15 measurements per year) instead of hourly observations, each was considered an event, as reflected in the Events statistics. Because of the few time steps with observation data, the Overall statistics were not calculated for the SBSA and SBSB datasets. The modeling fit statistics from all the tests are listed in Tables 7 through 15 . The closer the efficiency value is to 1.0 and the closer $R M S E(\mathrm{~m})$ and $M A E(\mathrm{~m})$ are to 0.0 , the more accurate the simulation. Figures 5 through 12 and Figure 14 show the observed and simulated SWE from all three snow models. Figures 13 and 15 show the observed and simulated SD from all three snow models for the SBSA and SBSB sites.

Table 7. Dry Lake, Colorado site SWE fit statistics.

\begin{tabular}{|l|l|l|l|l|l|l|}
\hline & \multicolumn{3}{|c|}{ Overall } & \multicolumn{3}{c|}{ Event } \\
\hline Model & NSE & RMSE & MAE & NSE & RMSE & MAE \\
\hline EB & 0.83 & 0.09 & 0.05 & 0.72 & 0.11 & 0.08 \\
\hline HY & 0.93 & 0.06 & 0.03 & 0.89 & 0.07 & 0.05 \\
\hline TI & 0.95 & 0.05 & 0.03 & 0.92 & 0.06 & 0.04 \\
\hline
\end{tabular}

*Shaded indicate the best fit. NSE (\%), RMSE (m), and MAE (m)

Table 8. Lost Horse, Washington site SWE fit statistics.

\begin{tabular}{|l|l|l|l|l|l|l|}
\hline & \multicolumn{3}{|c|}{ Overall } & \multicolumn{3}{c|}{ Event } \\
\hline Model & NSE & RMSE & MAE & NSE & RMSE & MAE \\
\hline EB & 0.76 & 0.08 & 0.05 & 0.60 & 0.11 & 0.08 \\
\hline HY & 0.86 & 0.06 & 0.04 & 0.82 & 0.08 & 0.05 \\
\hline TI & 0.89 & 0.06 & 0.03 & 0.87 & 0.06 & 0.04 \\
\hline
\end{tabular}

*Shaded indicate the best fit. NSE (\%), RMSE (m), and MAE (m) 
Table 9. Madison Butte, Oregon site SWE fit statistics.

\begin{tabular}{|l|l|l|l|l|l|l|}
\hline & \multicolumn{3}{|c|}{ Overall } & \multicolumn{3}{c|}{ Event } \\
\hline Model & NSE & RMSE & MAE & NSE & RMSE & MAE \\
\hline EB & 0.05 & 0.06 & 0.03 & -1.28 & 0.11 & 0.08 \\
\hline HY & 0.21 & 0.06 & 0.03 & -0.47 & 0.09 & 0.06 \\
\hline TI & 0.44 & 0.05 & 0.02 & 0.63 & 0.04 & 0.04 \\
\hline
\end{tabular}

*Shaded indicate the best fit.

$\operatorname{NSE}(\%), \operatorname{RMSE}(m)$, and MAE (m)

Table 10. Myrtle Creek, Idaho site SWE fit statistics.

\begin{tabular}{|l|l|l|l|l|l|l|}
\hline & \multicolumn{3}{|c|}{ Overall } & \multicolumn{3}{c|}{ Event } \\
\hline Model & NSE & RMSE & MAE & NSE & RMSE & MAE \\
\hline EB & 0.39 & 0.03 & 0.01 & -0.05 & 0.05 & 0.03 \\
\hline HY & 0.93 & 0.01 & 0.00 & 0.89 & 0.02 & 0.01 \\
\hline TI & -4.13 & 0.07 & 0.04 & -4.44 & 0.08 & 0.05 \\
\hline
\end{tabular}

*Shaded indicate the best fit.

NSE (\%), RMSE (m), and MAE (m)

Table 11. Sierra Blanca, New Mexico site SWE fit statistics.

\begin{tabular}{|l|l|l|l|l|l|l|}
\hline & \multicolumn{3}{|c|}{ Overall } & \multicolumn{3}{c|}{ Event } \\
\hline Model & NSE & RMSE & MAE & NSE & RMSE & MAE \\
\hline EB & 0.66 & 0.07 & 0.03 & 0.35 & 0.11 & 0.08 \\
\hline HY & 0.75 & 0.06 & 0.02 & 0.54 & 0.10 & 0.07 \\
\hline TI & 0.79 & 0.05 & 0.02 & 0.65 & 0.08 & 0.05 \\
\hline
\end{tabular}

*Shaded indicate the best fit.

NSE (\%), RMSE (m), and MAE (m)

Table 12. Sheldon, Nevada site SWE fit statistics.

\begin{tabular}{|l|l|l|l|l|l|l|}
\hline & \multicolumn{3}{|c|}{ Overall } & \multicolumn{3}{c|}{ Event } \\
\hline Model & NSE & RMSE & MAE & NSE & RMSE & MAE \\
\hline EB & 0.25 & 0.01 & 0.00 & -1.93 & 0.02 & 0.01 \\
\hline HY & -0.76 & 0.01 & 0.00 & -0.25 & 0.01 & 0.01 \\
\hline TI & 0.18 & 0.01 & 0.00 & 0.19 & 0.01 & 0.01 \\
\hline
\end{tabular}

* Shaded indicate the best fit.

NSE (\%), RMSE (m), and MAE (m) 
Table 13. Hagan's Meadow, California site SWE fit statistics.

\begin{tabular}{|l|l|l|l|l|l|l|}
\hline & \multicolumn{3}{|c|}{ Overall } & \multicolumn{3}{c|}{ Event } \\
\hline Model & NSE & RMSE & MAE & NSE & RMSE & MAE \\
\hline EB & 0.37 & 0.13 & 0.06 & -0.35 & 0.19 & 0.14 \\
\hline HY & 0.78 & 0.07 & 0.03 & 0.75 & 0.08 & 0.05 \\
\hline TI & 0.82 & 0.07 & 0.04 & 0.67 & 0.09 & 0.07 \\
\hline
\end{tabular}

*Shaded indicate the best fit.

$\operatorname{NSE}(\%), \operatorname{RMSE}(m)$, and MAE (m)

Table 14. Swamp Angel, Colorado site SWE fit statistics.

\begin{tabular}{|l|l|l|l|l|l|l|}
\hline & \multicolumn{3}{|c|}{ Overall } & \multicolumn{3}{c|}{ Event } \\
\hline Model & NSE & RMSE & MAE & NSE & RMSE & MAE \\
\hline EB & N/A & N/A & N/A & -1.95 & 0.39 & 0.31 \\
\hline HY & N/A & N/A & N/A & 0.10 & 0.21 & 0.11 \\
\hline TI & N/A & N/A & N/A & 0.82 & 0.10 & 0.07 \\
\hline
\end{tabular}

*Shaded indicate the best fit.

NSE (\%), RMSE (m), and MAE (m)

Table 15. Senator Beck Basin, Colorado site SWE fit statistics.

\begin{tabular}{|l|l|l|l|l|l|l|}
\hline & \multicolumn{3}{|c|}{ Overall } & \multicolumn{3}{c|}{ Event } \\
\hline Model & NSE & RMSE & MAE & NSE & RMSE & MAE \\
\hline EB & N/A & N/A & N/A & 0.41 & 0.16 & 0.14 \\
\hline HY & N/A & N/A & N/A & 0.70 & 0.11 & 0.08 \\
\hline TI & N/A & N/A & N/A & 0.61 & 0.13 & 0.11 \\
\hline
\end{tabular}

*Shaded indicate the best fit.

NSE (\%), RMSE (m), and MAE (m)

\subsection{Dry Lake, Colorado site results}

As shown in Table 7, this site had the highest fit between observed and simulated SWE. It also had one of the highest SWE volumes with water year SWE maximums ranging from $0.4 \mathrm{~m}$ and almost $1.0 \mathrm{~m}$. As expected, Figure 5 shows that the EB method uniformly underestimated SWE, while the HY and TI methods typically followed well with the observed SWE. The calibrated snow adjustment factor $(S C F)$ for the HY and TI methods was around 1.0, while the EB method had a value of 1.2. This highlights the fact that the EB method overestimates melt even when a high $S C F$ value is used. 


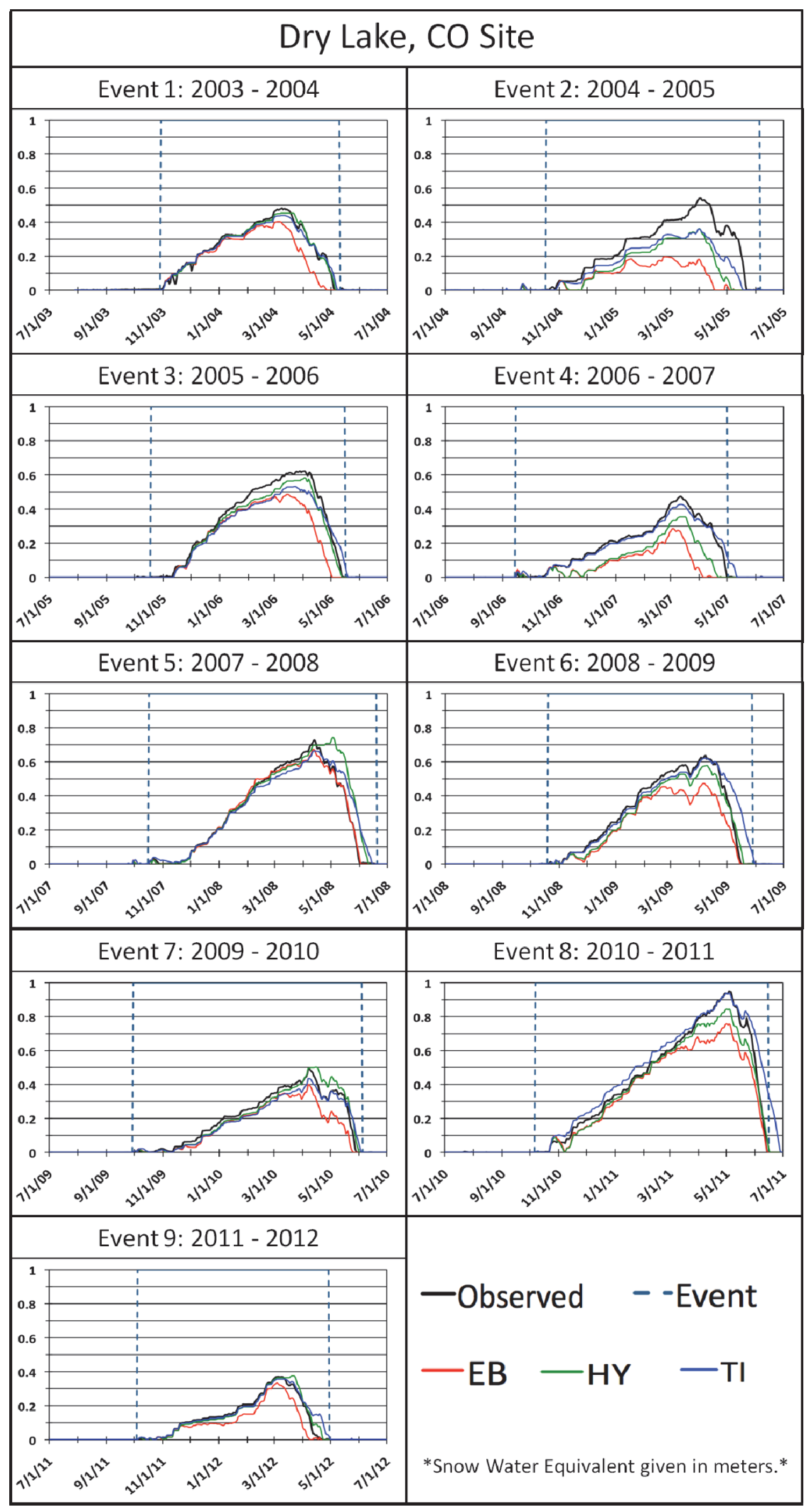

Figure 5. Dry Lake, Colorado SWE results (B). 


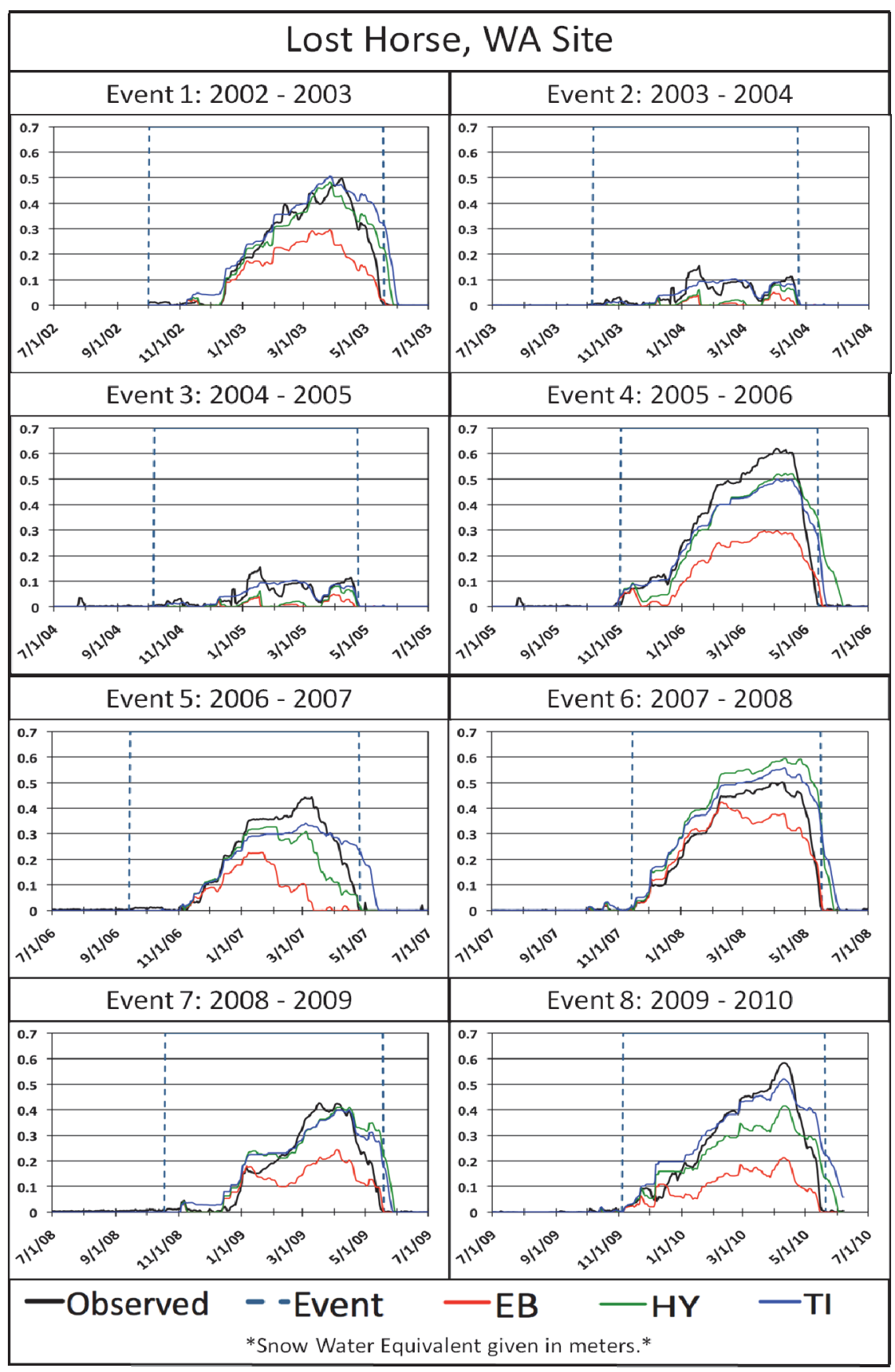

Figure 6. Lost Horse, Washington SWE results (B).

\subsection{Lost Horse, Washington site results}

The HY and TI simulated SWE matched well with the observed SWE at the Lost Horse site. Even with a good fit, the $H Y$ and $T I$ methods did prolong the snow past observed during Events 1 and 4 through 9 (Figure 6). It is evident, at this site in particular, how the EB underestimates the SWE compared to the HY and TI methods, as evidenced in Figure 6 and Table 8 (EB has the lowest NSE values and the highest RMSE and MAE values). 


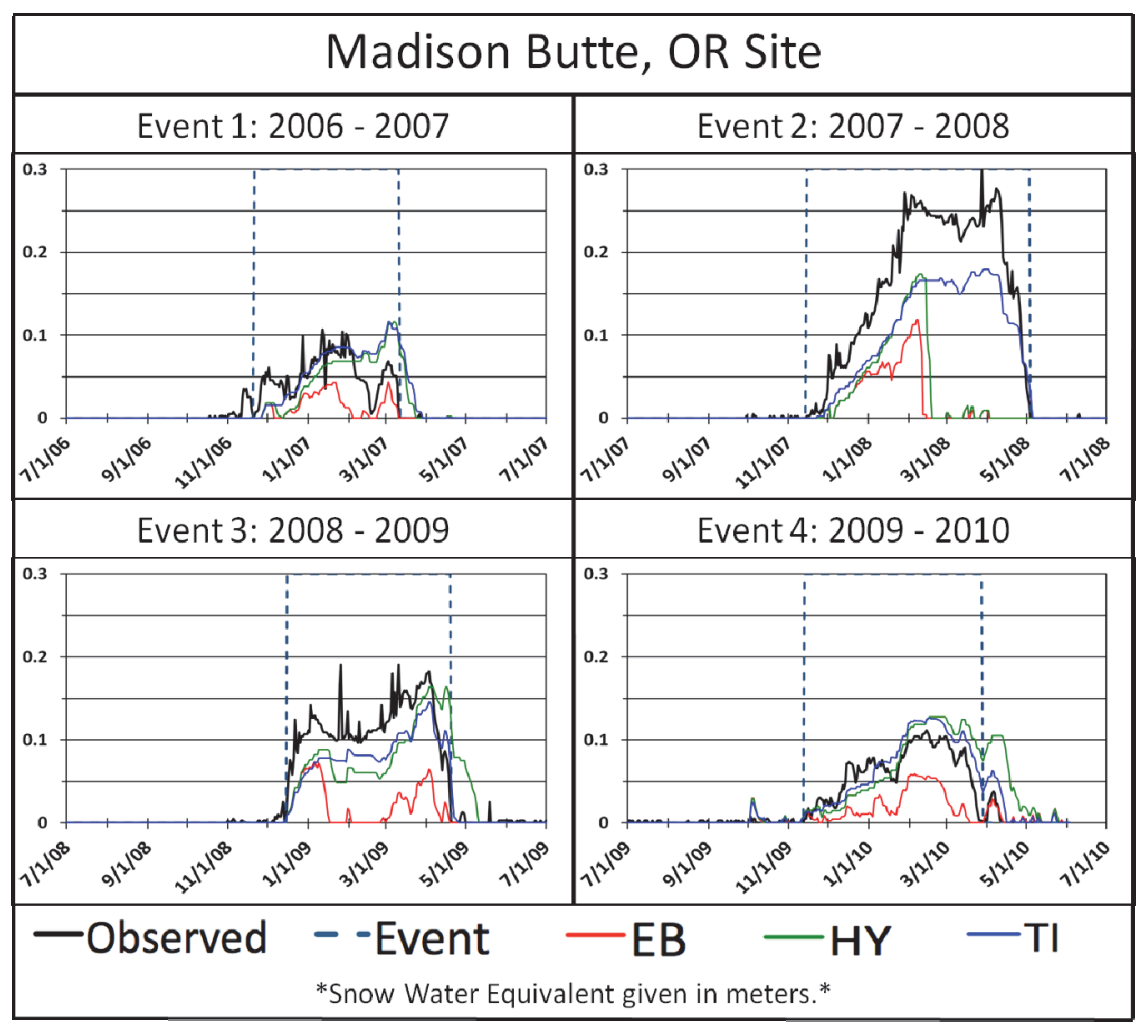

Figure 7. Madison Butte, Oregon SWE results.

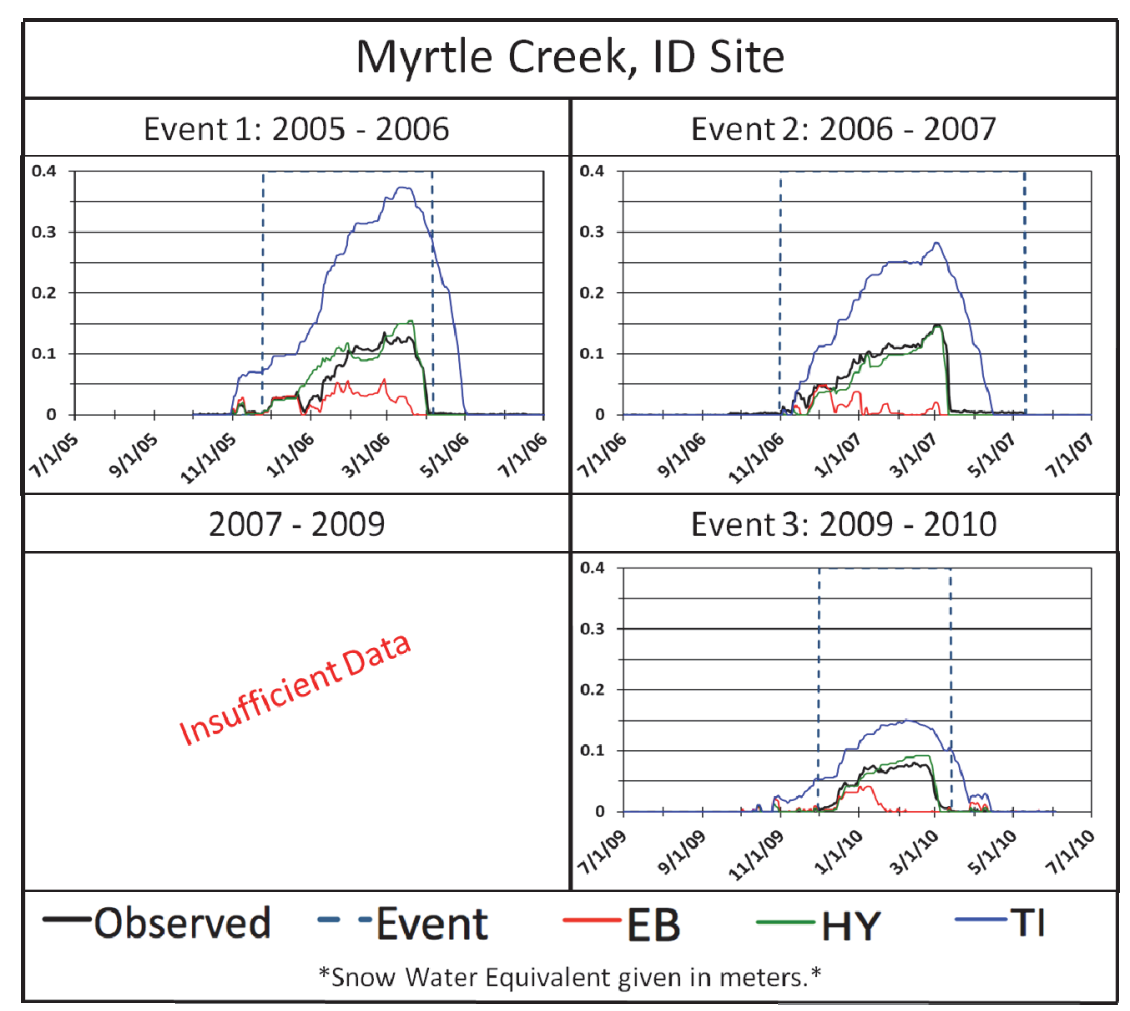

Figure 8. Myrtle Creek, Idaho SWE results. 


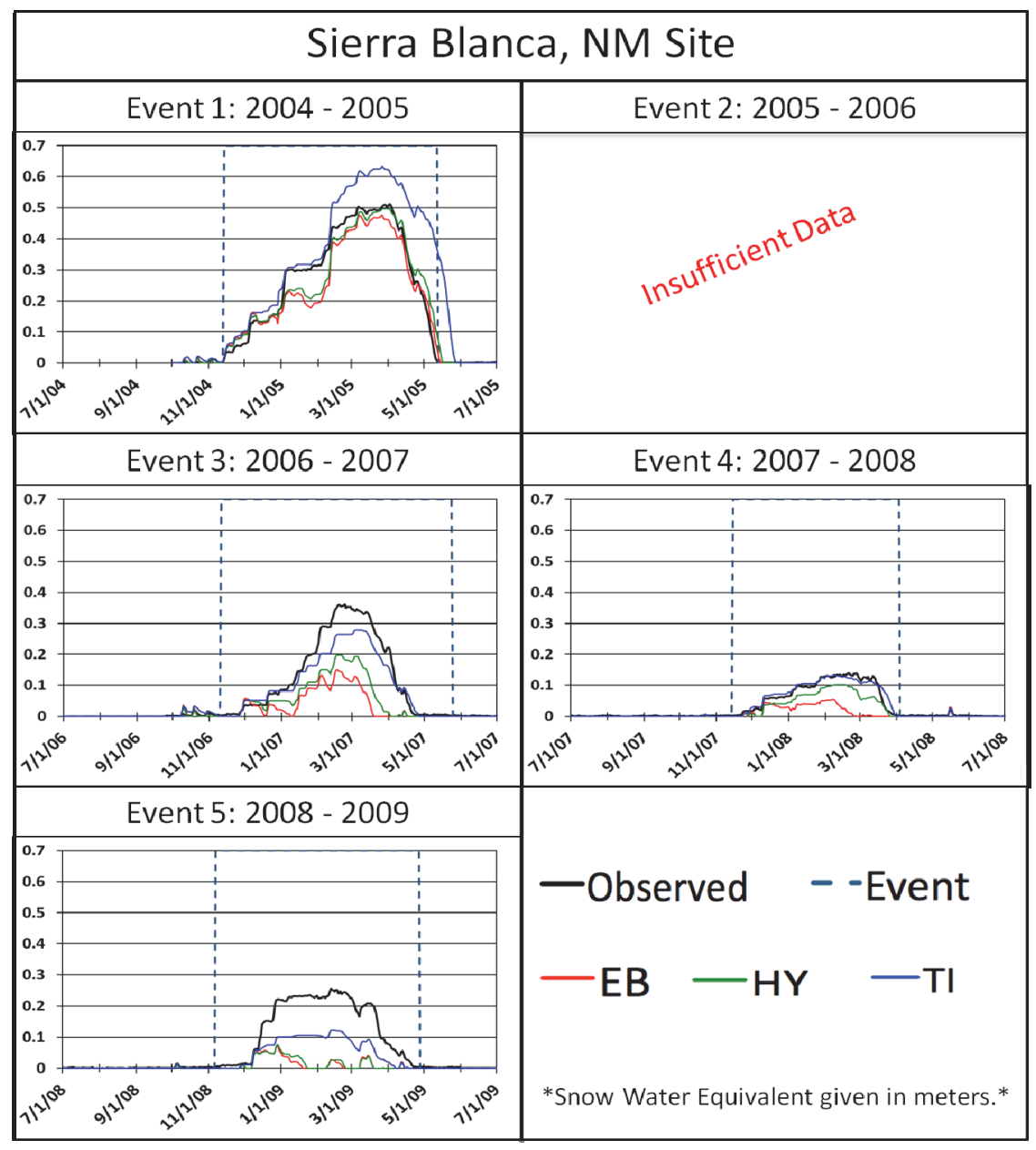

Figure 9. Sierra Blanca, New Mexico SWE results.

\subsection{Madison Butte, Oregon, site results}

The overall results from this site were poor. All three methods underestimated the SWE and the snowpack was simulated to last longer than observed (Figure 7). The relatively small snowpack (SWE maximum of $0.3 \mathrm{~m}$ ) might have skewed the results (even a relatively small error is magnified in such a small snowpack). As evidenced in Table 9, the TI method outperformed the energy balance based methods. This might be due to the ability of the TI method to better tune the model to observed data because it has nine calibrated parameters, rather than the four of the HY method and two of the EB method.

\subsection{Myrtle Creek, Idaho site results}

The calibrated TI method overestimated, the EB underestimated, and the HY method matched the SWE very well during every event at this site. The snow volumes were small (SWE max of $0.15 \mathrm{~m}$ ), but the HY method 
performed well, as seen in Figure 8 and Table 10. The poor results of the TI method could indicate an issue in basing all melt processes on one parameter, temperature. More investigation into this site might be required to fully determine the cause of this poor performance by the TI method.

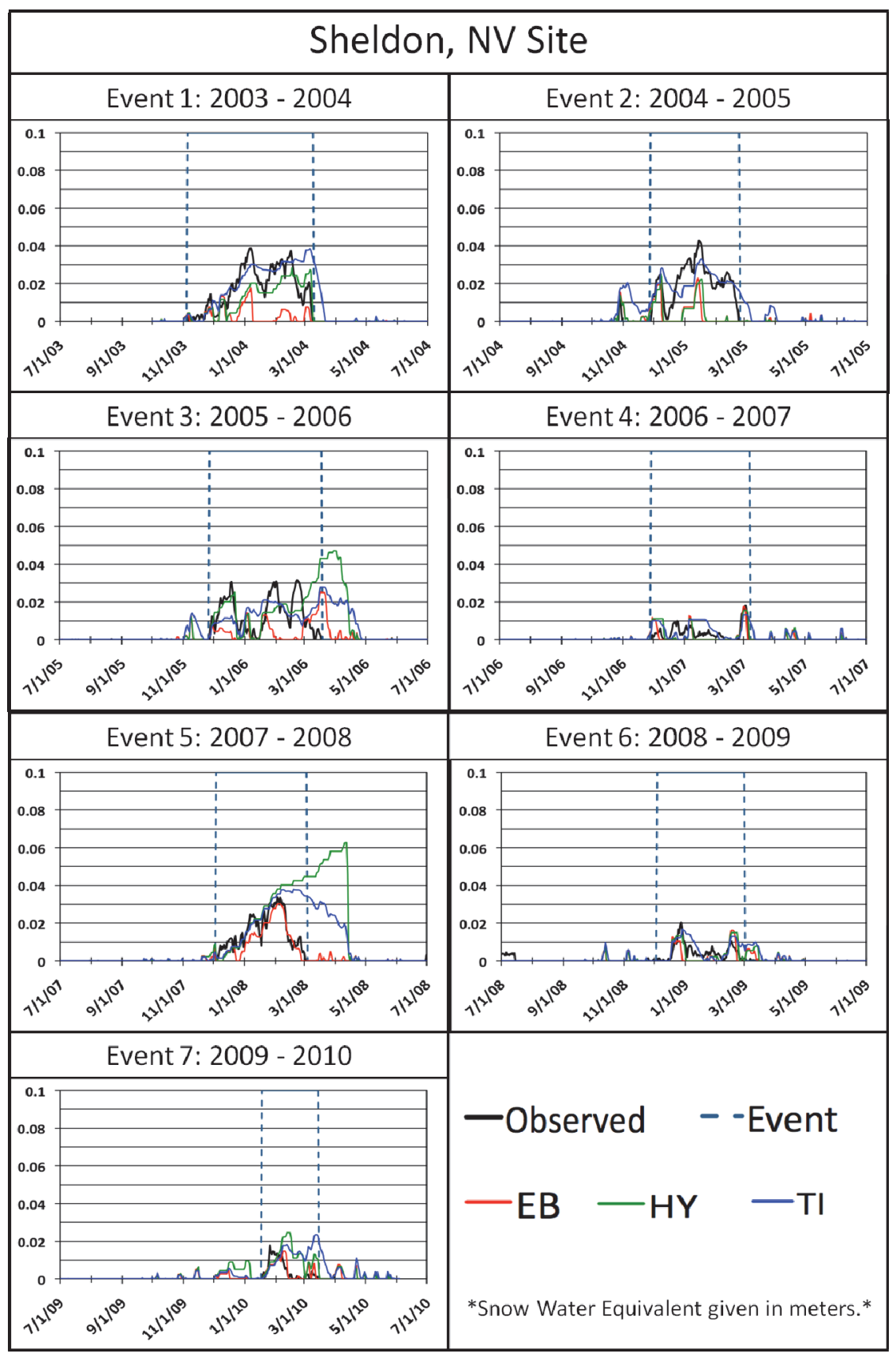

Figure 10. Sheldon, Nevada SWE results (A). 


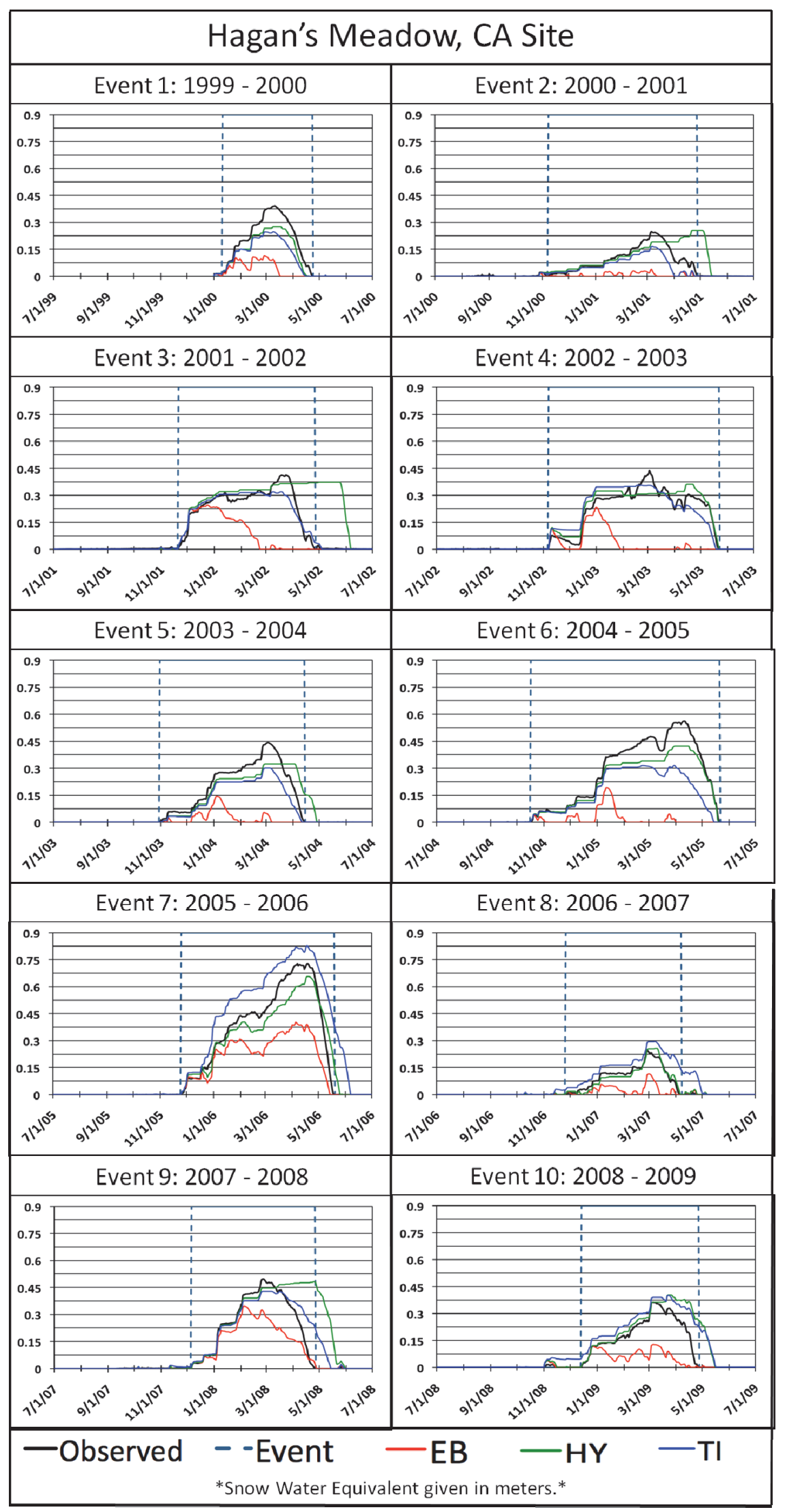

Figure 11. Hagan's Meadows, California SWE results (A). 


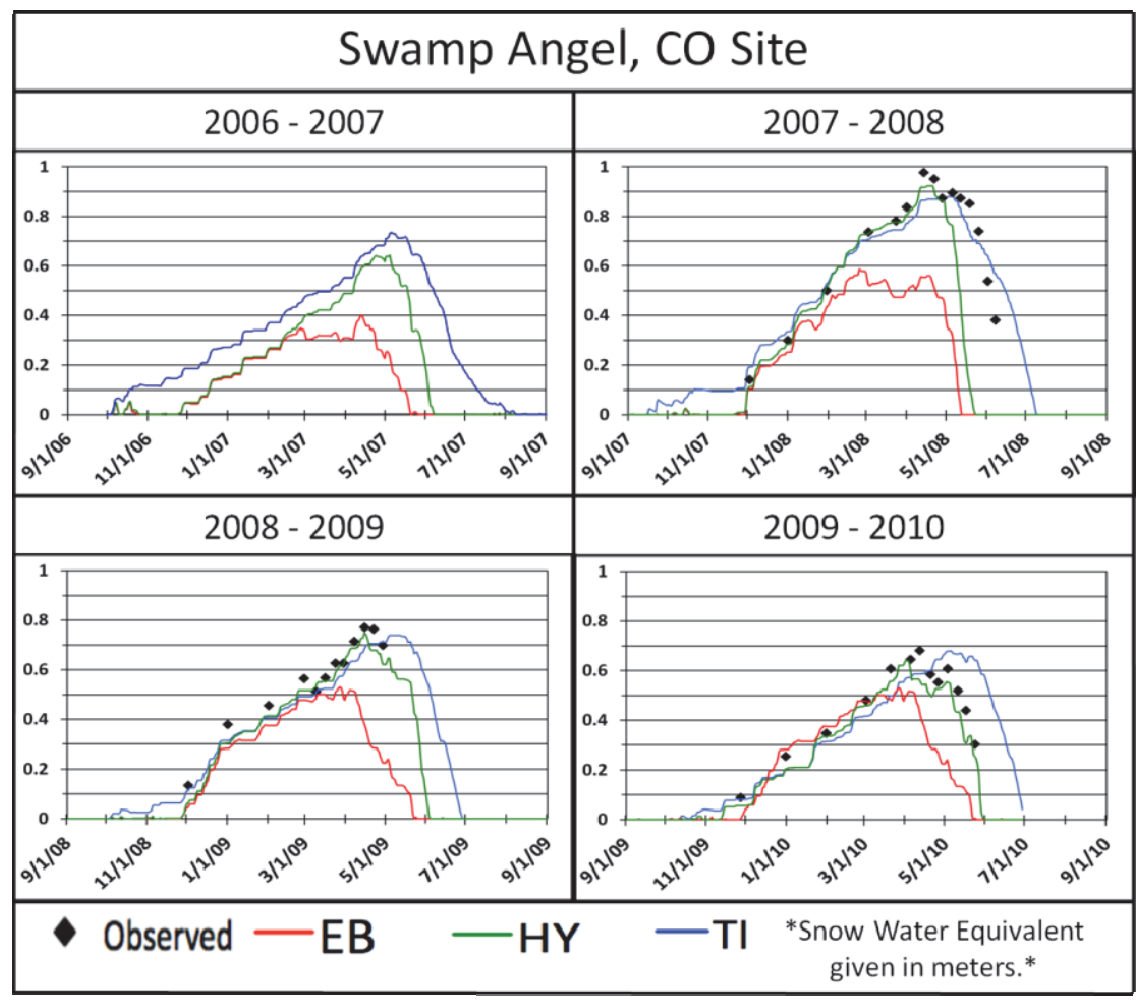

Figure 12. Swamp Angel study plot, Colorado, SWE results.

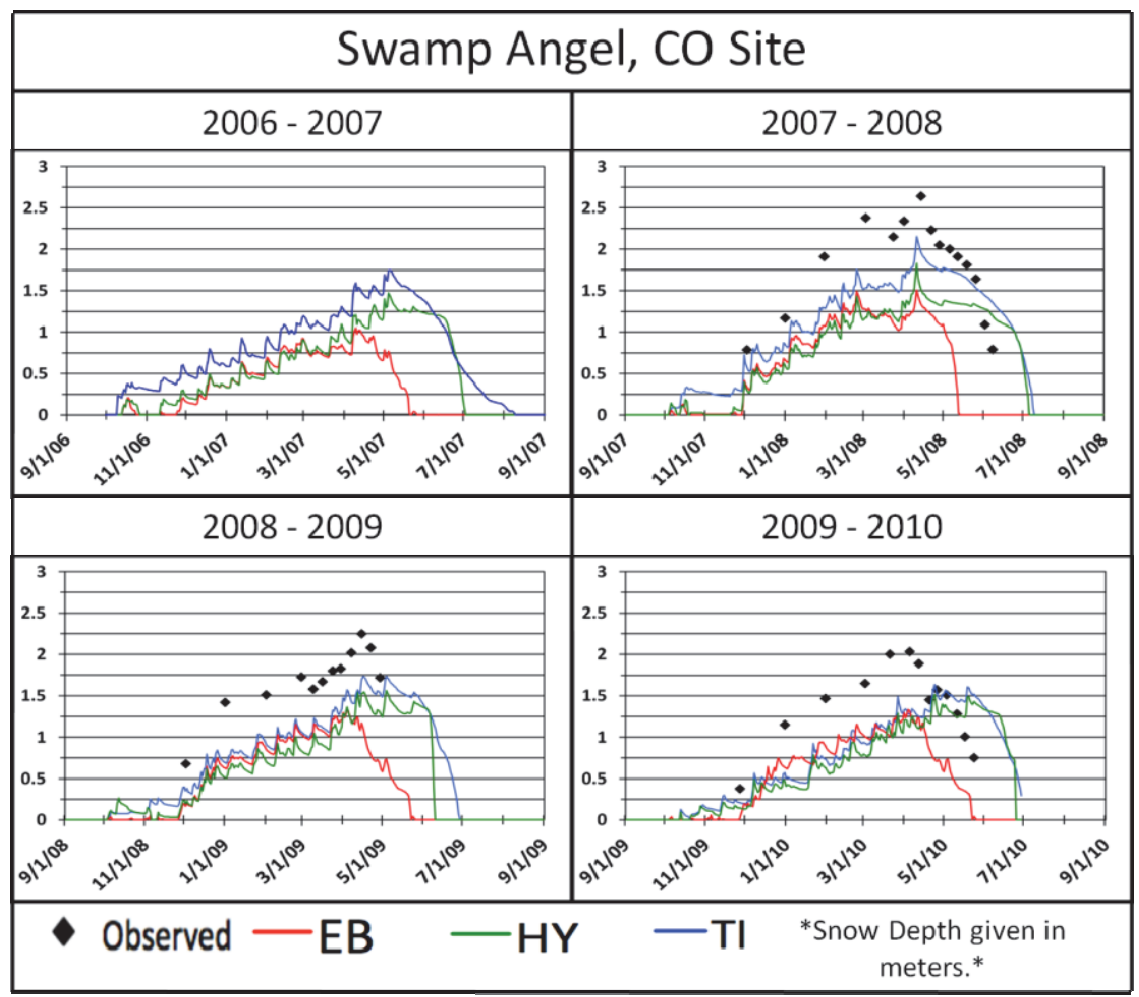

Figure 13. Swamp Angel study plot, Colorado, snow depth results. 


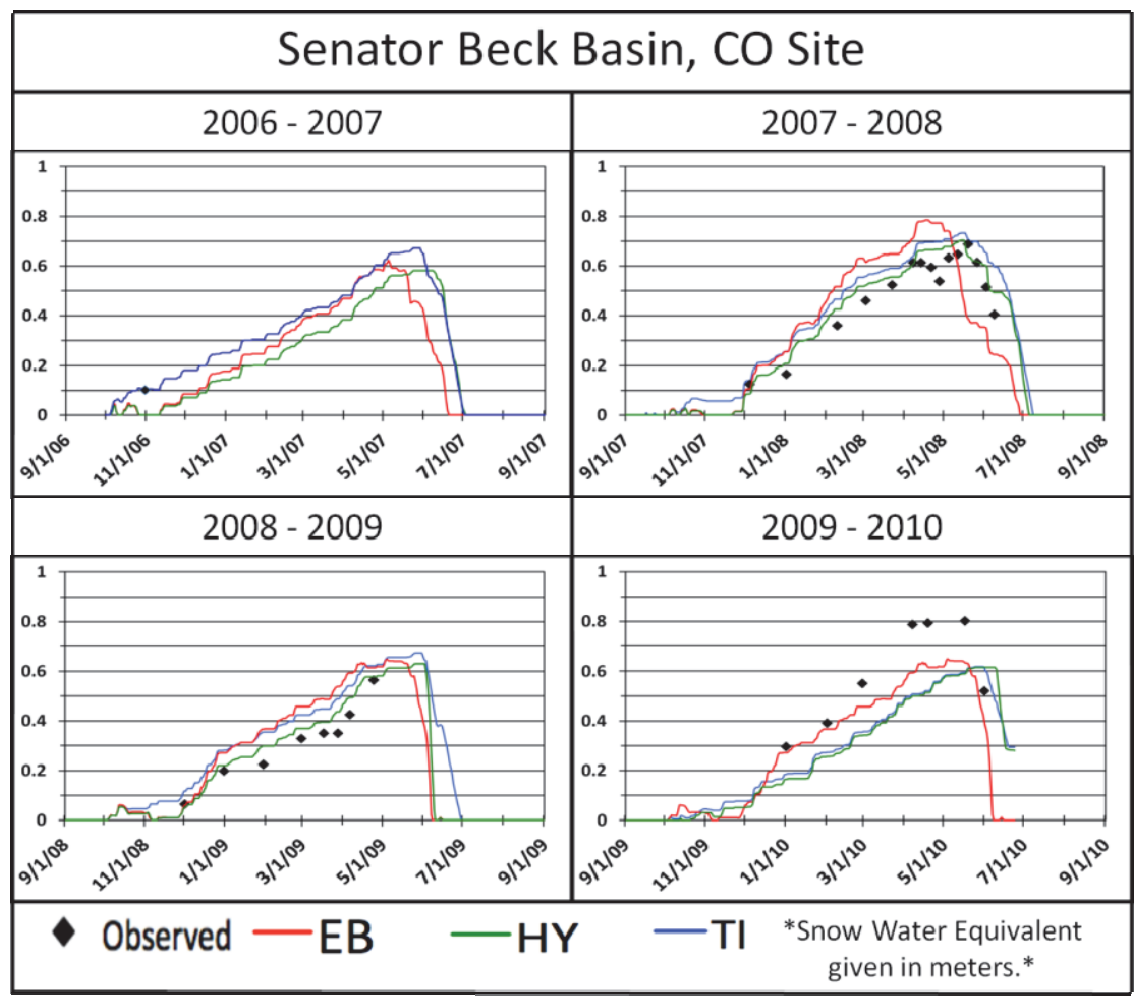

Figure 14. Senator Beck Basin study plot, Colorado, SWE results.

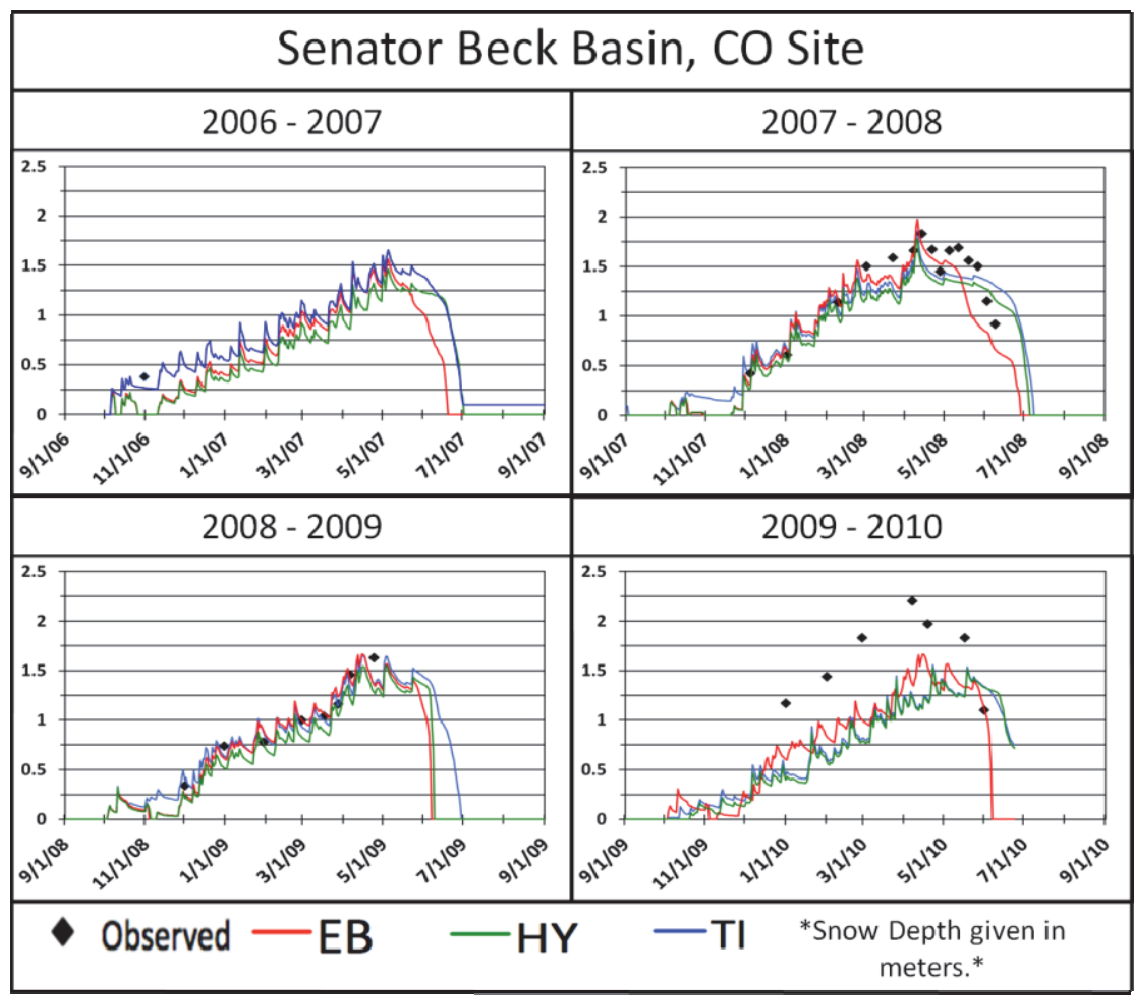

Figure 15. Senator Beck Basin study plot, Colorado, snow depth results. 


\subsection{Sierra Blanca, New Mexico, site results}

The first event (Figure 9) at this site was best simulated using the HY method. All other events were modeled best using the TI method. Compared to the other sites, the Sierra Blanca site had a medium snowpack with a maximum SWE of $0.5 \mathrm{~m}$.

\subsection{Sheldon, Nevada, site results}

This site had the worst results of all sites analyzed. It also had the smallest snowpack of any site, with a maximum SWE of just 0.042-m. The EB method performed best in Events 4 through 6, (Figure 10). This site indicates the EB method might perform well in shallow snowpacks where overcoming the heat deficit prior to melt is not physically relevant.

\subsection{Hagan's Meadow, California, site results}

This site had the longest period of record of any of the test sites. As evidenced in Figure 11 and Table 13, both the HY and TI methods performed consistently well at this site. The EB method consistently underestimated the SWE. The HY method accurately captured the accumulation and melt in Events 4, 7, and 8, and over- or underestimated the SWE in the other events. In Events 3, 5, and 9 the HY method prolonged the snowpack much longer than the observed record. This prolonging of the snowpack is not captured within the Event statistics because they are only calculated while snow is present in the observed record. For this reason, despite the Event results in Table 13, the TI method likely outperformed the HY method.

\subsection{Swamp Angel, Colorado, site results}

For the Swamp Angel site, the TI method performed the best, followed by the HY and the EB methods. Sporadic observed SWE readings prevented the Overall statistics from being computed. The Event fit statistics (Table 14) show that the TI method performed best. Visually from Figure 12, the HY method performs very well except for the melting in the 2007 to 2008 plot. Although the SWE results were accurate, Figure 13 shows the snow depth was consistently underestimated. 


\subsection{Senator Beck Basin, Colorado, site results}

For this site, the HY method performed the best, followed by the $T I$ and EB methods. Sporadic observed SWE readings prevented the Overall statistics from being computed. The Event fit statistics (Table 15) show the HY method performs best. Visually from Figure 14, all methods slightly overestimated SWE, except for the 2009 to 2010 plot when SWE was underestimated. Figure 15 shows that the snow depth results were accurate, except for the 2009 to 2010 plot where the simulations underestimated snow depth. 


\section{Conclusions}

The results presented clearly demonstrate the new snow models, temperature-index (TI) and hybrid energy balance (HY), now present within GSSHA outperform the original snow model, energy balance (EB), which consistently underestimated SWE. With the addition of the heat deficit, the snowpack tends to accumulate more and melt slower than when the original EB method was used, in most cases making the simulation more accurate. The importance of including the heat deficit is further evidenced by the EB model performing best at sites with a small snowpack. At these sites accounting for the heat deficit will make a minimal difference because the small snowpack likely has a small heat deficit to overcome. In comparison, sites with larger snowpacks, and therefore a larger heat deficit, were best simulated by the TI and HY models, which account for the heat deficit.

For most of the simulations, the TI model performed best, but this model requires nine calibration parameters. When deploying a model in a datapoor environment, use of the HY model is advised because it performs well with only four calibration parameters (included in the four are two associated with snow accumulation routines, which are not specific to the melt method deployed). At sites with a small snowpack (Sheldon, Nevada and Myrtle Creek, Idaho) the EB and HY models outperformed or performed nearly as well as the TI model. For this reason, use of the HY model is advised in areas with a small maximum snowpack ( 0.15-m SWE or less).

The snow depth simulations shown in Figures 13 and 15 show that when the SWE is simulated accurately, the SNAP model (in the form of subroutines now within GSSHA) simulates the snow depth reasonably. The results show that the SNAP subroutines might slightly overestimate snow depth when compared to observed data.

Overall, the GSSHA model has been improved by the inclusion of the HY and TI snow melt methods, as well as modifications to how snow fall accumulation is simulated. GSSHA can now more accurately simulate snow accumulation and melt within each cell, better capturing the snowpack and melt over an entire watershed. 


\section{References}

Albert, M., and G. Krajeski 1998. A fast, physically based point snowmelt model for use in distributed applications. Hydrological Processes 12(10-11): 1809-1824.

Anderson, E. A. 1973. National Weather Service River Forecast System - Snow Accumulation and Ablation Model. U. S. N. O. a. A. Administration. Silver Spring, Maryland.

Anderson, E. A. 1978. Streamflow simulation models for use on snow covered watersheds. In Proceedings on Modeling of Snow Cover Runoff. Hanover, NH: US Army Cold Regions Research and Engineering Laboratory.

Anderson, E. A. 2006. Snow Accumulation and Ablation Model - SNOW-17. NWSRFS User Documentation.

Blöschl, G., and R. Kirnbauer. 1991. Point snowmelt models with different degrees of complexity - Internal processes. Journal of Hydrology 129(1-4): 127-147.

Colbeck, S. C. 1991. The layered character of snow covers. Reviews of Geophysics 29(1): 81-96.

Doherty, J., L. Brebber, and P. Whyte. 2002. PEST-Modelling Independent Parameter Estimation. Corinda, Australia: Water Mark Computing.

Downer, C. W., and F. L. Ogden. 2004. GSSHA: Model to simulate diverse stream flow producing processes. Journal of Hydrologic Engineering 9(3): 161-174.

Downer, C. W., and F. L. Ogden. 2006. GSSHA Users' Manual. E. C. SR-06-1. Vicksburg, MS: US Army Engineer Research and Development Center.

Jordan, R. 1991. A One-Dimensional Temperature Model for a Snow Cover: Technical Documentation for SNTHERM. 89. U. A. C. o. Engineers. Hanover, NH: Cold Regions Research and Engineering Laboratory.

Jordan, R. 1998. A One-Dimensional Temperature Model for a Snow Cover: Technical Documentation for SNTHERM.89. U. A. C. o. Engineers. Hanover, NH: Cold Regions Research and Engineering Laboratory.

Kirnbauer, R., G. Bloeschl, and D. Gutknecht. 1994. Entering the era of distributed snow models. Nordic Hydrology 25(1): 1-24.

Melloh, R. A. 1999. A Synopsis and Comparison of Selected Snowmelt Algorithms. C. R. R. a. E. L. United States Army Corps of Engineers.

Nash, J. E., and J. V. Sutcliffe. 1970. River flow forecasting through conceptual models part I - A discussion of principles. Journal of Hydrology 10(3): 282-290.

National Snow and Ice Data Center (NSIDC). 2012. How Snow Forms. All About Snow. Accessed August 16, 2012 from http://nsidc.org/cryosphere/snow/science/formation.html. 


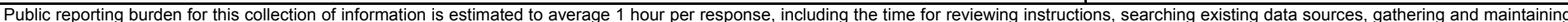

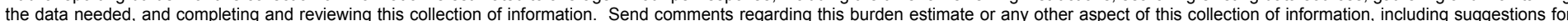

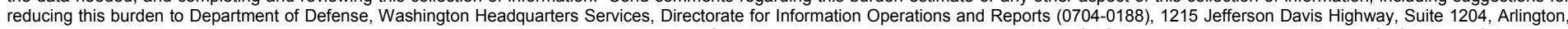

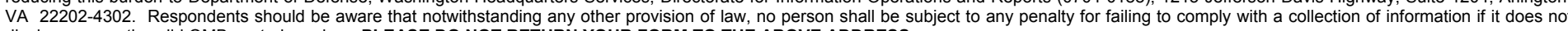
display a currently valid OMB control number. PLEASE DO NOT RETURN YOUR FORM TO THE ABOVE ADDRESS.

\begin{tabular}{|l|l|l|} 
1. REPORT DATE (DD-MM-YYYY) & 2. REPORT TYPE & 3. DATES COVERED (FrOm - To)
\end{tabular} June 2013

\section{TITLE AND SUBTITLE} Final

Snow Water Equivalent Modeling Capabilities of the GSSHA Watershed Model

5a. CONTRACT NUMBER

\section{Snow Water Equivalent Modeling Capabilities of the GSSHA Watershed Model}

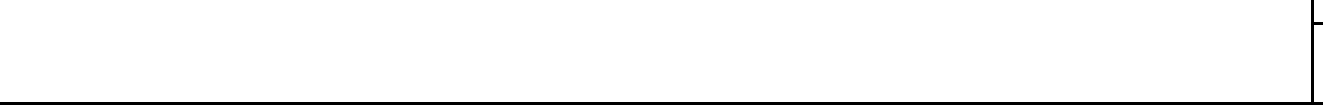

\section{AUTHOR(S)}

5d. PROJECT NUMBER

Michael L. Follum and Charles W. Downer

5e. TASK NUMBER

5f. WORK UNIT NUMBER

LB182K

\section{PERFORMING ORGANIZATION NAME(S) AND ADDRESS(ES)}

Coastal and Hydraulics Laboratory

US Army Engineer Research and Development Center

8. PERFORMING ORGANIZATION REPORT NUMBER

3909 Halls Ferry Road

Vicksburg, MS 39180

9. SPONSORING / MONITORING AGENCY NAME(S) AND ADDRESS(ES)

Headquarters, US Army Corps of Engineers

Washington, DC 20314-1000

ERDC/CHL TR-13-4

10. SPONSOR/MONITOR'S ACRONYM(S)

11. SPONSOR/MONITOR'S REPORT NUMBER(S)

\section{DISTRIBUTION / AVAILABILITY STATEMENT}

Approved for public release; distribution is unlimited.

\section{SUPPLEMENTARY NOTES}

\section{ABSTRACT}

This report demonstrates the snow water equivalent (SWE) modeling capabilities present within the Gridded Surface Sub-surface Hydrologic Analysis (GSSHA) model (Downer and Ogden 2004, 2006) by comparing simulated and observed snow accumulation data. GSSHA is used to simulate runoff, streamflow, and sediment and constituent transport in military and civil works projects. An energy balance method was originally used for calculating snow accumulation and melt, but now GSSHA has an optional temperature-index method and hybrid energy method. The full snowpack modeling capabilities of the Snowmelt Numerical-Analytical Package (SNAP) model (Albert and Krajeski 1998) have been included to simulate snowpack depth and density regardless of which snow accumulation model was used. With proficient SWE modeling capabilities, the GSSHA model can be utilized to solve complex watershed-related issues in regions where snow accumulation and melt are often the most critical source of water.

\begin{tabular}{|c|c|c|c|c|c|}
\hline $\begin{array}{l}\text { 15. SUBJECT TERMS } \\
\text { GSSHA } \\
\text { Modeling }\end{array}$ & $\begin{array}{l}\text { Snow } \\
\text { Snow water equivalent (SWE) } \\
\text { Watershed }\end{array}$ \\
\hline \multicolumn{1}{|l|}{ 16. SECURITY CLASSIFICATION OF: } & $\begin{array}{l}\text { 17. LIMITATION } \\
\text { OF ABSTRACT }\end{array}$ & $\begin{array}{l}\text { 18. NUMBER } \\
\text { OF PAGES }\end{array}$ & $\begin{array}{l}\text { 19a. NAME OF RESPONSIBLE } \\
\text { PERSON }\end{array}$ \\
\cline { 1 - 3 } $\begin{array}{c}\text { a. REPORT } \\
\text { Unclassified }\end{array}$ & b. ABSTRACT & c. THIS PAGE & & $\begin{array}{l}\text { 19b. TELEPHONE NUMBER (include } \\
\text { area code) }\end{array}$ \\
\end{tabular}

